\title{
Dietary exposure of three passerine species to PCDD/DFs from the Chippewa, Tittabawassee, and Saginaw River floodplains, Midland, Michigan, USA
}

\author{
Timothy B. Fredricks • John P. Giesy • Sarah J. Coefield • Rita M. Seston • \\ Melissa M. Haswell • Dustin L. Tazelaar • Patrick W. Bradley • \\ Jeremy N. Moore • Shaun A. Roark • Matthew J. Zwiernik
}

Received: 17 August 2009 / Accepted: 15 January 2010 / Published online: 10 February 2010

(C) The Author(s) 2010. This article is published with open access at Springerlink.com

\begin{abstract}
Dietary exposure of house wrens (Troglodytes aedon), tree swallows (Tachycineta bicolor), and eastern bluebirds (Sialia sialis) to polychlorinated dibenzofurans (PCDFs) and polychlorinated dibenzo- $p$-dioxins (PCDDs) near Midland, Michigan (USA) was evaluated based on site-specific data, including concentrations of
\end{abstract}

Electronic supplementary material The online version of this article (doi:10.1007/s10661-010-1319-5) contains supplementary material, which is available to authorized users.

T. B. Fredricks · J. P. Giesy

S. J. Coefield · R. M. Seston

Department of Zoology, Michigan State University,

East Lansing, MI 48824, USA

T. B. Fredricks $(\varangle)$

Bayer CropScience, Ecotoxicology,

17745 South Metcalf, Stilwell, KS 66085, USA

e-mail: fredri29@msu.edu

J. P. Giesy

Department of Veterinary Biomedical Sciences and Toxicology Centre, University of Saskatchewan, Saskatoon, Saskatchewan, Canada S7J 5B3

\section{J. P. Giesy}

Department of Biology and Chemistry,

City University of Hong Kong, Kowloon,

Hong Kong SAR, China residues in bolus samples and individual invertebrate orders and dietary compositions by study species. Site-specific dietary compositions for the three species were similar to those reported in the literature, but differed in their relative proportions of some dietary items. Oligocheata (non-depurated) and Brachycera (Diptera) contained the greatest average concentrations of $\Sigma$ PCDD/DFs of the major site-specific dietary items collected via food web-based sampling. Average ingestion values of $\Sigma$ PCDD/DFs from site-specific bolus-based and food web-based

\section{J. P. Giesy}

College of Environment, Nanjing University

of Technology, Nanjing, 210093,

People's Republic of China

J. P. Giesy

Key Laboratory of Marine Environmental Science, College of Oceanography and Environmental Science,

Xiamen University, Xiamen, People's Republic of China

M. M. Haswell

Science Department, Davenport University, Midland, MI 48640, USA

D. L. Tazelaar · P. W. Bradley •

J. N. Moore · M. J. Zwiernik

Department of Animal Science, Michigan State

University, East Lansing, MI 48824, USA

S. A. Roark

ENTRIX, Inc., Okemos, MI 48864, USA 
dietary concentrations for nestlings at study areas (SAs) were 6- to 20-fold and 2- to 9-fold greater than at proximally located reference areas (RAs), respectively. Average ingestion values of total 2,3,7,8-tetrachlorodibenzo- $p$-dioxin equivalents (TEQ $\left.{ }_{\mathrm{WHO}-\mathrm{Avian}}\right)$ from site-specific bolus-based and food web-based dietary concentrations for nestlings at SAs were 31- to 121-fold and 9- to 64-fold greater than at proximally located RAs, respectively. Estimates of $\Sigma \mathrm{PCDD} / \mathrm{DFs}$ and TEQ ${ }_{W H O-A v i a n}$ tissue concentrations based on nestling dietary exposures were greater than those measured. Plausible explanations include nestling metabolism of 2,3,7,8-tetrachlorodibenzofuran and assimilation rates of less than the $70 \%$ assumed to occur over the nestling growth period. Profiles of the relative concentrations of individual $\mathrm{PCDD} / \mathrm{DF}$ congeners in samples of invertebrates and bolus at SAs on the Tittabawassee River downstream of the source of contamination were dominated by $1,2,3,4,6,7,8,9$ octachlorodibenzo-p-dioxin ( $22 \%$ to $44 \%$ ) and 2,3,7,8-tetrachlorodibenzofuran ( $18 \%$ to $50 \%)$.

Keywords Furans $\cdot$ Dioxins $\cdot$ Bolus $\cdot$ Birds • TEQs $\cdot$ Invertebrates

\section{Introduction}

Site-specific dietary exposure to polychlorinated dibenzofurans (PCDFs) and polychlorinated dibenzo- $p$-dioxins (PCDDs) was determined for three cavity-nesting, insectivorous passerine species downstream of Midland, Michigan (USA). Tree swallows (Tachycineta bicolor), which eat primarily emergent aquatic invertebrates (McCarty 1997; McCarty and Winkler 1999; Mengelkoch et al. 2004), have been shown to have exposure links to contaminated sediments (Custer et al. 1998; Echols et al. 2004; Maul et al. 2006; Neigh et al. 2006c; Papp et al. 2007; Smits et al. 2005). House wrens (Troglodytes aedon) and eastern bluebirds (Sialia sialis) have been used to assess the contaminant exposure of terrestrial insectivores at locations with contaminated soils (Neigh et al. 2006a). Both species primarily feed on terrestrial invertebrates (Beal 1915; Guinan and Sealy 1987). However, they have different habitat preferences and foraging strategies which may influence contaminant exposure.

PCDFs, and to a lesser extent PCDDs, are present at elevated concentrations in the Tittabawassee and Saginaw rivers downstream of Midland, Michigan and appear to have originated from the production, storage, and disposal of organic chemicals prior to the establishment of modern waste management protocols (Amendola and Barna 1986). Total concentrations of PCDD/DFs ( $\Sigma$ PCDD/DFs) in floodplain soils and sediments, from the study area (SA), ranged from $1.0 \times 10^{2}$ to $5.4 \times 10^{4} \mathrm{ng} / \mathrm{kg}$ dry weight, while mean $\Sigma$ PCDD/PCDF concentrations in soils and sediments in the reference area (RA) upstream of Midland were 10- to 20-fold less (Hilscherova et al. 2003).

Usually, PCDD/DFs, polychlorinated biphenyls (PCBs), and similar chlorinated hydrocarbons occur in the environment as mixtures. The mixture of chlorinated hydrocarbons in the SA is dominated by a few PCDF congeners, which makes it distinctive compared to other locations contaminated with PCB mixtures or PCDDs (Custer et al. 2002, 2005, 2006; Froese et al. 1998; Harris and Elliott 2000; Neigh et al. 2006b, c; Secord et al. 1999; Shaw 1983; Smits et al. 2005; Spears et al. 2008). Furthermore, based on chemical characteristics and best estimates of historical production data, it is likely that this unique mixture has been in place for almost a century, with most of the materials being released prior to the 1950s (ATS 2007, 2009).

PCDFs and related chlorinated hydrocarbons are persistent and lipophilic (Mandal 2005) and have a great potential to accumulate through the food web (Blankenship et al. 2005; Custer et al. 1998; Kay et al. 2005; Maul et al. 2006; Russell et al. 1999; Smits et al. 2005; Wan et al. 2005). Because of the elevated soil and sediment concentrations in the SA (Hilscherova et al. 2003) and low avian dietary exposure thresholds (Custer et al. 2005; Eisler 2000; Nosek et al. 1992), the authors investigated the potential for the accumulation of PCDFs and PCDDs from invertebrates to resident insectivorous birds. 
Complex relationships exist between sitespecific contaminant concentrations, dietary exposure pathways, and resulting tissue concentrations. In particular, concentrations of chlorinated hydrocarbons and the congener profiles of the relative concentrations of congeners have been shown to be site-specific (Custer and Read 2006; Maul et al. 2006; Papp et al. 2007). Site-specific dietary composition is related to the prevailing invertebrate abundance (Custer et al. 2005; Echols et al. 2004; Neigh et al. 2006a; Nichols et al. 1995; Quinney and Ankney 1985; Smits et al. 2005; Wayland et al. 1998) and the timing of nest initiation (Custer et al. 1998; Maul et al. 2006; Papp et al. 2007), especially for tree swallows that prey primarily on emergent aquatic invertebrates to feed nestlings (Blancher and McNicol 1991; Johnson and Lombardo 2000; McCarty and Winkler 1999). Site-specific residue concentrations in egg and nestling tissues have been studied for a variety of chlorinated hydrocarbons and species (Ankley et al. 1993; Bishop et al. 1995; Custer et al. 1998, 2003, 2005; Froese et al. 1998; Henning et al. 2003; Neigh et al. 2006a, b, c; Spears et al. 2008). Fewer studies have investigated accumulation via the diet or determined uptake rates (Echols et al. 2004; Nichols et al. 1995, 2004).

The primary objectives of this study were to characterize dietary exposure of adults and nestlings of three insectivorous passerine species representing different feeding guilds with different pathways of exposure to PCDD/DFs and to compare concentrations and congener profiles of composited site-specific food web-based dietary samples to bolus samples. Bolus samples are actual dietary samples collected by the adult birds for comparison to the dietary concentrations estimated using residue concentrations of invertebrates collected at each site. By comparing the bolus-based dietary samples with the food web-based dietary estimates based on site-specific percent dietary compositions and concentrations in food web items, it can be determined whether invertebrates collected in the biological sampling areas (BSAs) are truly representative of the congener profile and concentrations fed to on-site nestlings. A secondary objective was to determine how well estimates of dietary exposure based on site-specific dietary composition and accumulation factors from the literature correspond to measured concentrations in nestlings (Fredricks et al. 2010a).

The study examined four endpoints: (1) site-specific dietary composition by species; (2) concentrations of $\Sigma \mathrm{PCDD} / \mathrm{DF}$ and 2,3,7,8tetrachlorodibenzo- $p$-dioxin (TCDD) equivalents (TEQWHO-Avian) based on World Health Organization (WHO) TCDD equivalency factors for

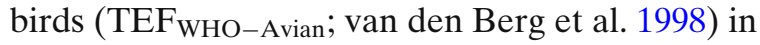
food web-based composited invertebrate samples and bolus samples for each species; (3) spatial and species-specific trends in concentrations; and (4) patterns of relative concentrations of individual congeners. Comparisons of congener-specific concentrations stratified by feeding pathway and area were made to provide insight into the contaminants source and species-specific exposures. This information can be used to estimate exposure of other species to the contaminants.

\section{Methods}

Site description

Study locations were selected on the Tittabawassee, Chippewa, and Saginaw Rivers in the vicinity of Midland, Michigan (Fig. 1). Nest boxes were placed and prey items were collected from within the 100-year floodplain of the individual rivers. Two RAs were located upstream of the putative sources of PCDD/DFs (Hilscherova et al. 2003) on the Tittabawassee (R-1) and Chippewa (R-2) Rivers (Fig. 1). Study areas downstream of the putative sources of PCDD/DFs include approximately $72 \mathrm{~km}$ of freeflowing river from the upstream boundary defined as the low-head dam near Midland, Michigan through the confluence of the Tittabawassee and Saginaw Rivers to where the Saginaw River enters Saginaw Bay. The SAs within the Tittabawassee River area included four locations (T-3 to T-6) approximately equally spaced and locations (S-7 to S-9) which are at the initiation, median, and terminus of the Saginaw River. The seven 


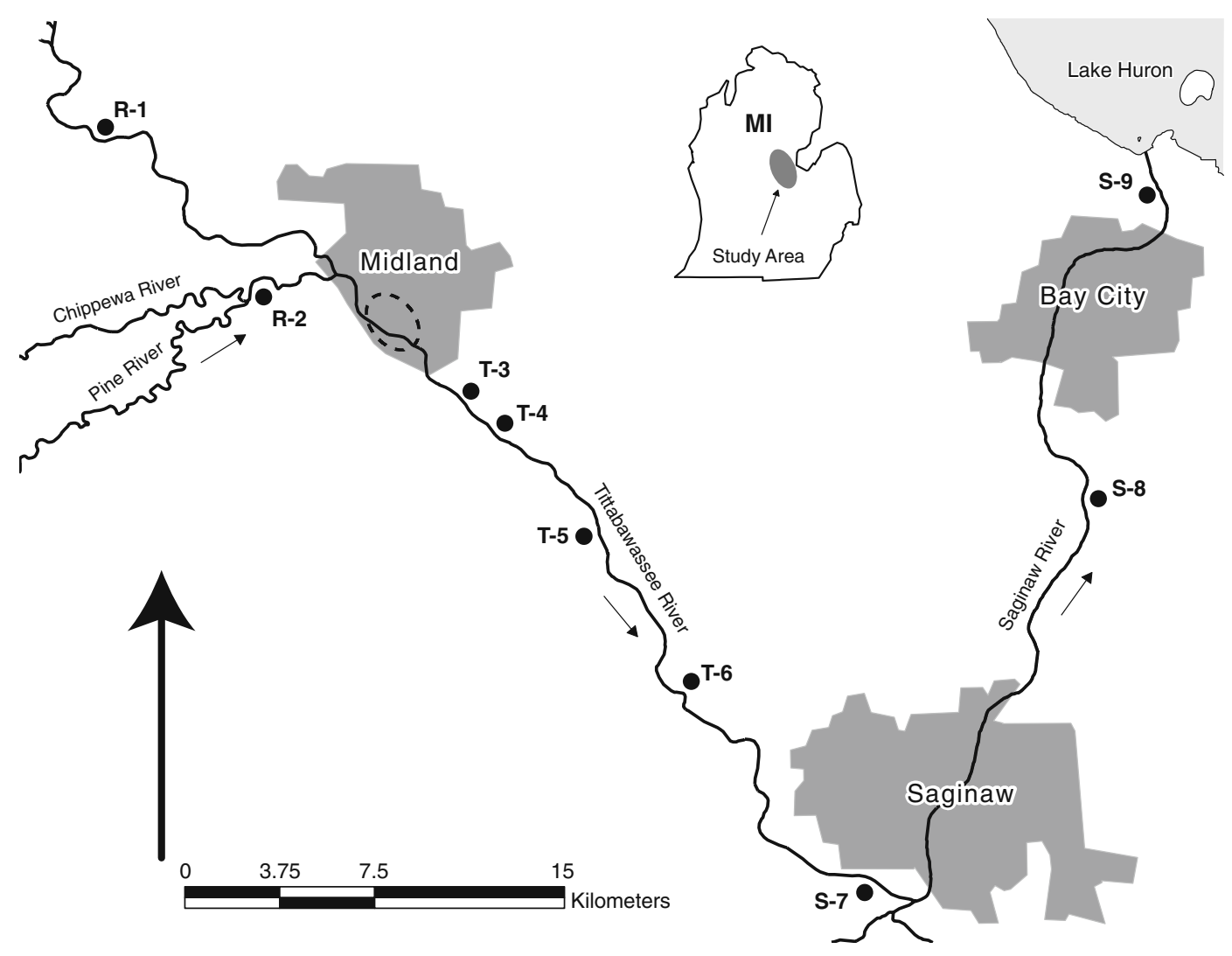

Fig. 1 Study site locations within the Chippewa, Tittabawassee, and Saginaw River floodplains, Michigan, USA. Reference areas (R-1 to R-2), Tittabawassee River study areas (T-3 to T-6), and Saginaw River Study Areas
(S-7 to S-9) were monitored from 2005 to 2007. Direction of river flow is designated by arrows; suspected source of contamination is enclosed by the dashed oval
SAs (T-3 to S-9) were selected based on the necessity to discern spatial trends, ability to gain access privileges, and maximal receptor exposure potential based on floodplain width and measured soil and sediment concentrations (Hilscherova et al. 2003). Nest box trails within RAs and SAs each contained between 30 and 60 nest boxes and spanned a continuous foraging area of between 1 and $3 \mathrm{~km}$ of river. S-8 was an exception and was only used for sediment and dietary food web sampling. No studies of birds were conducted at this location.

\section{Tissue collections}

Detailed site descriptions and protocols for collecting and handling samples of eggs and nestlings have been previously presented (Fredricks et al. 2010a). Briefly, nest boxes were monitored daily from mid-April through the end of the breeding season from 2005 to 2007. Eggs and nestlings were collected for quantification of PCDD/DFs. Nest boxes were randomly selected from the active nest boxes at a given location for either live egg or nestling collections, but not both. Abandoned and addled eggs were salvaged opportunistically. Fresh and addled eggs were collected from 49 house wren, 50 tree swallow, and 35 eastern bluebird nests during the 2005-2007 breeding seasons. Nestlings were collected from 48 house wren nests at 10-day post hatch, while nestlings were collected from 45 tree swallow and 30 eastern bluebird nests at 14-day post hatch. Nestlings collected were of similar mass to adult birds and 
approximately 3 to 5 days before the typical fledge date for each species. Adult passerines were not collected for quantification of residues because part of the research focused on long-term adult and nestling survival and recruitment.

Measurement endpoints associated with productivity (Fredricks et al. 2010b) included egg mass, clutch size, hatching success, fledgling success, total productivity, and nestling growth. Masses of nestlings were made 3-, 6-, 9-, and 10day post-hatch for house wrens and 4-, 8-, 12-, and 14-day post-hatch for tree swallows and eastern bluebirds. Species- and site-specific nestling growth curves were utilized in the dietary exposure assessments presented.

Food web sampling

Collection of invertebrates occurred at nine predetermined BSAs that were located within the RA and SA locations. Each BSA included two $30 \times 30$-m grids proximal to the river bank, one for terrestrial sampling and one for aquatic sampling. Study area BSA locations were selected based on maximizing the potential for collecting food items with the greatest contaminant concentrations for a given nest box trail given the available soil and sediment data.

Site-specific sampling of invertebrates took place during 2003 at R-1, R-2, T-4, and T-6, 2004 at R-1, R-2, and T-3 to T-6, and 2006 at S-7 to S-9. Temporal variation in the composition of sampled species and potential concentration differences were accounted for by collecting samples at multiple times throughout the breeding season (midMay, June, and August). During each sampling period, all samples for that period were collected within a 6-day window to minimize temporal variation. All collected invertebrates were transferred to a labeled, chemically clean glass jar (I-CHEM, Rockwood, TN). Sampling was terminated upon the collection of approximately $5 \mathrm{~g}$ or more biomass per order. Samples were stored on wet ice while in the field and transferred to a $-20^{\circ} \mathrm{C}$ freezer until categorization and homogenization. Sampling methods were designed to target aquatic emergent insects, benthic invertebrates, and terrestrial invertebrates through specific methodolo- gies that maximized invertebrate biomass and diversity of collected samples.

Collection of aquatic emergents

Aquatic emergent insects were collected with a modified form of aerial trap called a light screen, which targeted flying adult aquatic insects. Collections began at dusk and continued for 1 to $3 \mathrm{~h}$ at each location or until invertebrate encounter frequency declined. A metal halide light attracted invertebrates to a white sheet, and invertebrates were collected in Insect Vac Collection Chambers and Insect Vacs (Bioquip Products, Rancho Dominguez, California). Aerial nets were used to collect airborne invertebrates that did not land on the sheet.

\section{Collection of benthic invertebrates}

Aquatic macroinvertebrates were collected by use of several different methods depending on the habitat type at each collection location. Sampling methods used included individual picking with forceps from submerged woody debris; cobble and aquatic vegetation; sieve bucket; and D-frame kick net. Sampling occurred during daylight hours at all locations.

Collection of soil, terrestrial plants, and invertebrates

Sampling techniques used to collect soil and terrestrial plants and invertebrates at each location employed a four-tiered approach: (1) a $1 \times 1-\mathrm{m}$ plot was randomly selected from within a BSA and one or more composite plant samples were collected based on plant diversity; (2) soil was excavated by hand digging to a depth of $15 \mathrm{~cm}$; a soil composite sample and all resident Oligocheata were collected; (3) forceps were used to collect surface-dwelling terrestrial invertebrates from the soil surface and leaf litter; and (4) aerial or plant perching invertebrates were collected using sweep nets and/or aerial invertebrate nets. Oligocheata were rinsed in distilled water prior to chemical analyses. 
Sorting of invertebrates

Invertebrates were categorized taxonomically to the order level for each life stage collected during each sampling period per site. For emergent insects, the order Diptera was divided into the suborders Nematocera (primarily aquatic) and Brachycera (primarily terrestrial) to account for possible exposure differences during the larval life stages (Merritt and Cummins 1996). Samples were then homogenized and stored at $-20^{\circ} \mathrm{C}$ until extraction.

\section{Sampling of food bolus}

Dietary food items were collected as bolus samples from nestling house wrens, tree swallows, and eastern bluebirds following the methods described by Mellott and Woods (1993). Briefly, nestlings between the ages of 3- and 9-day post-hatch for house wrens or 4- and 12-day post-hatch for tree swallows and eastern bluebirds were fitted with a black electrical cable tie (10.2-cm size) around the base of their neck. The use of a cable tie allows finite adjustments and maximizes collection potential while minimizing bias associated with loss of smaller invertebrates (McCarty and Winkler 1991) and nestling mortalities. Ligatured nestlings were observed for 20-30 s to observe for unnatural behaviors such as pronounced gasping or struggling. Bolus sampling occurred throughout the day to account for any temporal variation in invertebrate abundance or activity. Bolus samples were collected from nestlings $1 \mathrm{~h}$ after ligature application. Bolus material found in the nest cavity was also collected. Nests were randomly selected for bolus sampling, and nests were not sampled on consecutive days. Nest boxes were concurrently sampled for nestling growth and reproductive parameters. Both this and other studies have shown that there is no discernable difference in growth of nestlings from boxes that do or do not have samples of boluses collected (Neigh et al. 2006a). Additionally, adult tree swallows deliver food to the nest approximately18 times per hour throughout the day (McCarty 2002), so dietary sampling should only represent a small portion of a nestling's daily food requirements.
Estimation of site-specific diet

The site-specific diet was based on the relative proportion of the total mass represented by each invertebrate order identified in the bolus samples. Invertebrates in each bolus sample were classified to order (Merritt and Cummins 1996), and the total number and mass of each order was recorded for each sample. The site-specific diet obtained from the bolus samples was used in the estimate of food web-based dietary exposure described subsequently.

\section{Bolus sample residue analysis}

Where possible, bolus samples were recombined for residue analyses based on the clutch from which they were collected. For clutches lacking sufficient biomass of bolus for residue analyses ( 3-5 g), bolus samples were combined within a study area from proximally located nest boxes until the necessary biomass was obtained. Due to limited biomass from house wren bolus samples at $\mathrm{R}-1$, samples from this area were combined from 2005 and 2006.

Identification and quantification of PCDD/DF congeners

Concentrations of seventeen 2,3,7,8-substituted $\mathrm{PCDD} / \mathrm{DF}$ congeners were measured in all invertebrate and bolus samples that had enough biomass to meet analytical requirements. Based on the contribution of PCBs to the total TEQs ${ }_{\text {WHO-Avian }}$ in the soil/sediment samples collected from the Tittabawassee River during the screening level assessment (Hilscherova et al. 2003), PCBS were not analyzed in passerine dietary items. PCDD/DFs were quantified in accordance with EPA Method 8290 with minor modifications (US Environmental Protection Agency (USEPA) 1998). Briefly, samples were homogenized with anhydrous sodium sulfate and Soxhlet-extracted in hexane/dichloromethane (1:1) for $18 \mathrm{~h}$. Before extraction, known amounts of ${ }^{13} \mathrm{C}$-labeled analytes (15 of the seventeen 2,3,7,8-substituted PCDD/DF congeners; OCDF and 1,2,3,4,7,8-HxCDD were not included) were 
added to each sample as internal standards. The extraction solvent was exchanged to hexane and the extract was concentrated to $10 \mathrm{~mL}$. Ten percent of this extract was removed for lipid content determination. Extracts were initially purified by treatment with concentrated sulfuric acid. The extract was then passed through a silica gel column containing silica gel and sulfuric acid silica gel and eluted with hexane. The extract received additional column chromatography by elution through acidic alumina, which resulted in two fractions. The first elution contained most of the PCBs and pesticide compounds, while the second fraction contained dioxins and furans. This second fraction was then passed through a carbon column packed with $1 \mathrm{~g}$ of activated carbonimpregnated silica gel. The first fraction of the silica gel was combined with the first fraction from the acidic alumina column and was retained for possible co-contaminant analyses. The second fraction of the silica gel, eluted with toluene, contained the 2,3,7,8-substituted PCDD/DFs. Components were analyzed using HRGC-HRMS, a Hewlett-Packard 6890 GC (Agilent Technologies, Wilmington, DE) connected to a MicroMass ${ }^{\circledR}$ high-resolution mass spectrometer (Waters Corporation, Milford, MA). PCDF and PCDD congeners were separated on a DB-5 capillary column (Agilent Technologies) coated at $0.25 \mu \mathrm{m}$ $(60-\mathrm{m} \times 0.25-\mathrm{mm}$ i.d.). The mass spectrometer was operated at an EI energy of $60 \mathrm{eV}$ and an ion current of $600 \mu \mathrm{A}$. Congeners were identified and quantified by use of single ion monitoring at the two most intensive ions of the molecular ion cluster. Concentrations of 2,3,7,8tetrachlorodibenzofuran (TCDF) were confirmed using a DB-225 $(60-\mathrm{m} \times 0.25-\mathrm{mm}$ i.d., $0.25-\mu \mathrm{m}$ film thickness) column (Agilent Technologies). Chemical analyses included pertinent quality assurance practices, including matrix spikes, blanks, and duplicates.

\section{Dietary exposure calculations}

Dietary exposures of adult house wrens, tree swallows, and eastern bluebirds were estimated using the USEPA Wildlife Exposure Factors Handbook (WEFH; USEPA 1993) equations for passerine birds. Major factors influencing dietary exposure included daily food intake rate [IR; gram wet weight food/gram body weight $(\mathrm{BW}) /$ day], nestling or adult mass (BW), dietary concentrations (C), and uncertainty factors associated with availability of contaminants for absorption to the bird from the diet. United States EPA WEFH Equation 3-4 was used to calculate IR for adults. Equations to estimate food ingestion rate based on bioenergetics techniques (Nichols et al. 1995, 2004) were utilized for nestlings since USEPA WEFH Equation 3-4 is based on freeliving passerines.

Site-specific mean ( \pm standard deviation) adult masses used to calculate IR for house wrens, tree swallows, and eastern bluebirds were $11.2 \mathrm{~g}( \pm 1.3$; $n=349), 20.9 \mathrm{~g}( \pm 1.6 ; n=235)$, and $31.2 \mathrm{~g}( \pm 2.1$; $n=83)$, respectively. Species-specific nestling growth curves (Fredricks et al. 2010b) were used to estimate daily IR over the nesting period. Species-specific dietary concentrations in food items were estimated using two methods: (1) food web-based diet: multiplying study-specific dietary compositions for major ( $>1 \%$ by mass) prey items by respective area-specific (R-1 to R-2; T-3 to $\mathrm{T}-6$; $\mathrm{S}-7$ to $\mathrm{S}-9$ ) average, minimum, and maximum concentrations of $\Sigma$ PCDD/DFs in associated prey items for each study species and (2) bolus-based diet: area-specific average, minimum, and maximum concentrations from actual bolus samples collected from nestlings of each species studied. Minimum and maximum concentrations were chosen to cover the range of possible invertebrate concentrations found on-site, which the authors expected to include the worst-case scenario for dietary exposure.

Assimilation efficiency has been estimated to be $70 \%$ to $90 \%$ based on the results of a study of PCB exposures in which $70 \%$ was used (Nichols et al. 2004). Potential average daily dose ( $\mathrm{ADD}_{\mathrm{pot}}$; nanograms per kilogram per day) was calculated using Equation 4-3 (USEPA 1993) assuming that $100 \%$ of the foraging range for each species was within the associated study area (McCarty and Winkler 1999). Average nestling concentrations of $\Sigma$ PCDD/DFs were estimated for house wren nestlings up to 10 day post-hatch and for tree swallow and eastern bluebird nestlings up to 14 day 
post-hatch since these are the respective days that nestlings were collected. Predictions of nestling body burdens incorporated maternal transfer of contaminants to the nestlings via the egg. Dietary exposure estimates apply only to the nesting period for both adults and nestlings because foraging habits and range are likely more variable outside the nesting period.

\section{Statistical analyses}

Total concentrations of the seventeen 2,3,7,8substituted PCDD/DF congeners are reported as the sum of all congeners (nanograms per kilogram wet weight (ww)). Individual congeners that were less than the limit of quantification were assigned a value of half the sample method detection limit. Concentrations of TEQ ${ }_{\mathrm{WHO}-\mathrm{Avian}}$ (nanograms per kilogram ww) were calculated for PCDD/DFs by summing the product of the concentration of each congener, multiplied by its avian $\mathrm{TEF}_{\mathrm{WHO}-\text { Avian }}$ (van den Berg et al. 1998). Samples of invertebrates from the food web were composites of all individuals of an order collected per location per sampling period. Arithmetic means (range) are presented (Tables 1 and 2).

Statistical analyses were performed using SAS® software (Release 9.1; SAS Institute Inc., Cary, NC, USA). Prior to the use of parametric statistical procedures, normality was evaluated using the Shapiro-Wilk's test, and the assumption of homogeneity of variance was evaluated using the Levene's test. Data that were not normally distributed were transformed using the natural $\log (\ln )$ of $(x+1)$ before statistical analyses. Concentrations in bolus samples by species studied and invertebrates by orders were tested for effects of study area on concentrations of both $\Sigma$ PCDD/DFs and TEQ ${ }_{W H O-A v i a n}$. The generalized linear model procedure (PROC GLM) was used to make comparisons for invertebrate orders when represented in the RA, Tittabawassee River SA, and Saginaw River SA. When significant differences among locations were indicated, Bonferroni's $t$ test was used to make comparisons between study areas. The $t$ test procedure (PROC TTEST) was used to make comparisons between bolus samples by species studied collected at RAs and SAs. For all
Table 1 Potential average (range) $\Sigma$ PCDD/DFs and

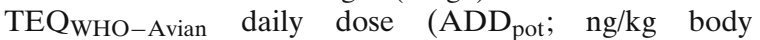
weight/day) calculated from site-specific bolus-based and food web-based dietary exposure for adult house wrens, tree swallows, and eastern bluebirds breeding during 20042006 within the Chippewa, Tittabawassee, and Saginaw River floodplains, Midland, Michigan, USA

\begin{tabular}{|c|c|c|c|c|}
\hline \multirow[t]{2}{*}{ Study area } & \multicolumn{2}{|l|}{ Bolus } & \multicolumn{2}{|l|}{ Food web } \\
\hline & $\Sigma \mathrm{PCDD} / \mathrm{DFs}$ & $\mathrm{TEQ}_{\mathrm{WHO}-\text { Avian }^{\mathrm{a}}}{ }^{\mathrm{a}}$ & $\overline{\Sigma P C D D / D F s}$ & TEQWHO-Avian \\
\hline \multicolumn{5}{|l|}{ House wren } \\
\hline $\mathrm{R}-1$ and R-2 & $26(12-45)^{\mathrm{c}, \mathrm{d}}$ & $1.1(0.73-1.7)$ & $36(10-76)$ & $1.5(0.54-3.0)$ \\
\hline T-3 to T-6 & $360(160-630)$ & $150(38-430)$ & $180(64-340)$ & $68(13-140)$ \\
\hline S-7 and S-9 & ${ }^{\mathrm{e}}$ & - & $140(20-710)$ & $16(5.9-34)$ \\
\hline \multicolumn{5}{|l|}{ Tree swallow } \\
\hline R-1 and R-2 & $53(16-90)$ & $4.9(1.4-8.8)$ & $120(20-370)$ & $6.1(1.3-13)$ \\
\hline T-3 to T-6 & $340(58-1000)$ & $200(24-800)$ & $570(130-1400)$ & $250(34-630)$ \\
\hline S-7 and S-9 & - & - & $200(130-370)$ & $70(40-120)$ \\
\hline \multicolumn{5}{|l|}{ Eastern bluebird } \\
\hline R-1 and R-2 & $12(4.2-20)$ & $0.88(0.44-1.9)$ & 35 (10-92) & $1.1(0.47-2.2)$ \\
\hline T-3 to T-6 & $250(54-790)$ & $110(13-450)$ & $310(100-740)$ & $77(24-180)$ \\
\hline S-7 and S-9 & - & - & $240(84-720)$ & $41(6.2-110)$ \\
\hline
\end{tabular}

${ }^{\mathrm{a}}$ TEQWHO-Avian were calculated based on the 1998 avian WHO TEF values

${ }^{b}$ R-1 to R-2: Tittabawassee and Chippewa rivers reference area; T-3 to T-6: Tittabawassee River study area; S-7 to S-9: Saginaw River study area

${ }^{c}$ Values were rounded and represent only two significant figures

${ }^{\mathrm{d}}$ Food ingestion rate was calculated from equations in The Wildlife Exposure Factors Handbook (USEPA 1993)

${ }^{\text {e }}$ Residue analyses were not conducted on bolus collected invertebrates at S-7 and S-9 
Table 2 Average (range) calculated nestling concentrations of $\Sigma$ PCDD/DFs and TEQWHO-Avian (ng/kg ww) determined from site-specific bolus-based and food webbased dietary exposure for nestling house wrens, tree

\begin{tabular}{|c|c|c|c|c|}
\hline \multirow[t]{2}{*}{ Study area } & \multicolumn{2}{|l|}{ Bolus } & \multicolumn{2}{|l|}{ Food web } \\
\hline & $\Sigma \mathrm{PCDD} / \mathrm{DFs}$ & $\mathrm{TEQ}_{\text {WHO-Avian }}{ }^{\mathrm{a}}$ & $\Sigma \mathrm{PCDD} / \mathrm{DFs}$ & TEQWHO-Avian \\
\hline \multicolumn{5}{|l|}{ House wren $^{b}$} \\
\hline $\mathrm{R}-1$ and $\mathrm{R}-2^{\mathrm{c}}$ & $92(39-170)^{\mathrm{d}, \mathrm{e}}$ & $5.7(2.8-13)$ & $120(35-260)$ & $7.0(2.2-17)$ \\
\hline T-3 to T-6 & $1300(530-2800)$ & $570(130-1700)$ & $750(230-1,900)$ & $310(54-810)$ \\
\hline S-7 and S-9 & $-{ }^{\mathrm{f}}$ & - & $490(79-2,400)$ & $81(25-230)$ \\
\hline \multicolumn{5}{|l|}{ Tree swallow } \\
\hline R-1 and R-2 & $380(110-700)$ & $47(13-88)$ & $810(140-2,400)$ & $54(12-120)$ \\
\hline T-3 to T-6 & $2100(360-6200)$ & $1300(150-4900)$ & $3,600(790-8,500)$ & $1500(210-3,900)$ \\
\hline S-7 and S-9 & - & - & $1,200(830-2,300)$ & $440(250-790)$ \\
\hline \multicolumn{5}{|l|}{ Eastern bluebird } \\
\hline R-1 and R-2 & $91(31-160)$ & $8.1(3.4-20)$ & $250(72-650)$ & $9.4(3.6-22)$ \\
\hline $\mathrm{T}-3$ to $\mathrm{T}-6$ & $1800(380-5600)$ & $760(93-3200)$ & $2,200(710-5,300)$ & $560(160-1,300)$ \\
\hline S-7 and S-9 & - & - & $1,700(590-4,900)$ & $290(48-790)$ \\
\hline
\end{tabular}

${ }^{a}$ TEQWHO-Avian were calculated based on the 1998 avian WHO TEF values

${ }^{\mathrm{b}} \mathrm{HW}=10$-d nesting period; $\mathrm{TS}$ and $\mathrm{EB}=14-\mathrm{d}$ nesting period

c R-1 to R-2: Tittabawassee and Chippewa rivers reference area; T-3 to T-6: Tittabawassee River study area; S-7 to S-9: Saginaw River study area

dValues were rounded and represent only two significant figures

${ }^{\mathrm{e}}$ Food ingestion was calculated from equations in Nichols et al. (2004)

${ }^{\mathrm{f}}$ Residue analyses were not conducted on bolus collected invertebrates at S-7 and S-9

hypotheses tests, differences were considered to be statistically significant at $p=0.05$.

\section{Results}

\section{Dietary composition}

Sampling of boluses resulted in the collection of at least one invertebrate from nestlings in $86 \%, 93 \%$, and $86 \%$ of attempted bolus sampling events at selected house wren $(n=135)$, tree swallow $(n=96)$, and eastern bluebird $(n=51)$ nesting attempts, respectively. Sampling intensity and success were greatest in 2006, in part because of additional collection locations (S-7 and S-9) combined with greater sampling proficiency. The greatest number of individual invertebrates collected was from tree swallow nestlings, while the fewest were from eastern bluebird nestlings (Fig. 2). Eastern bluebirds consume fewer large invertebrates, tree swallows consume greater numbers of small invertebrates, and house wrens are intermediate. Invertebrate orders represented in bolus samples include Amphipoda, Araneae, swallows, and eastern bluebirds within the Chippewa, Tittabawassee, and Saginaw River floodplains during 2004-2006, Midland, Michigan, USA 

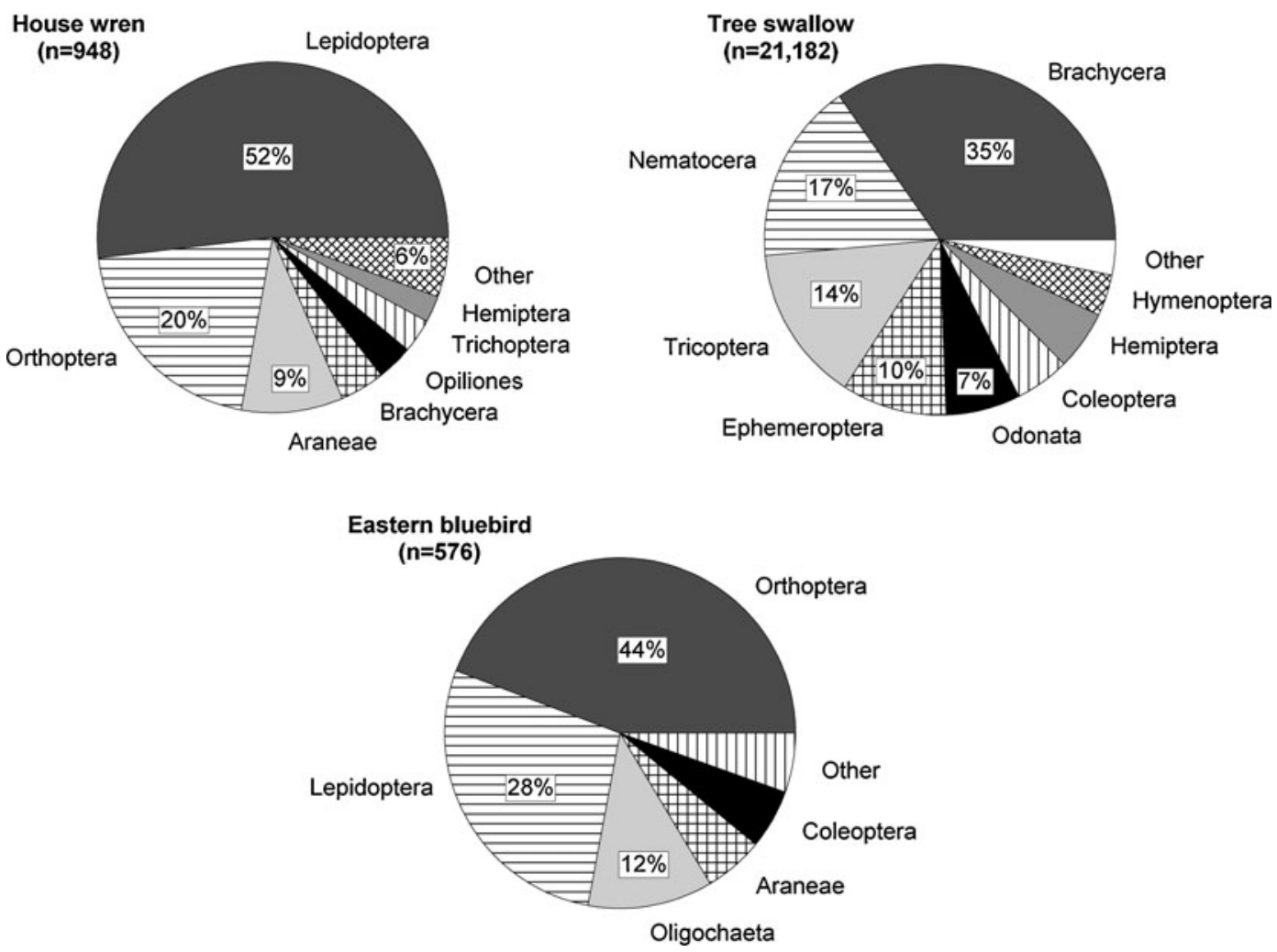

Fig. 2 Percent mass dietary compositions for house wrens, tree swallow, and eastern bluebirds collected in 20042006 from Chippewa, Tittabawassee, and Saginaw River

component. Generally, nestling tree swallows were fed fewer Trichoptera and more Coleoptera at downstream SAs relative to upstream RAs. Otherwise, species-specific dietary compositions between study sites were similar.

\section{$\Sigma$ PCDD/DFs and TEQswHO-Avian}

Concentrations of $\Sigma \mathrm{PCDD} / \mathrm{DFs}$ and TEQswHO-Avian in the majority of invertebrate orders were different among study areas, except concentrations of $\Sigma \mathrm{PCDD} / \mathrm{DFs}$ were spatially similar for the orders Araneae and Orthoptera. Eight invertebrate orders were classified as "important" based on dietary composition for each species studied and composed approximately $92 \%, 76 \%$, and $90 \%$ of the invertebrates consumed on-site by nestling house wrens, tree swallows, and eastern bluebirds, respectively (Fig. 2). Mean concentrations of $\Sigma$ PCDD/DFs floodplains near Midland, Michigan, USA. Percentages for orders over $5 \%$ and invertebrate sample size by species are indicated

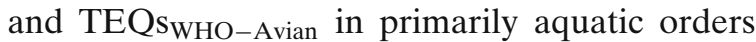
were $<1$ - to 10 -fold and 5- to 59-fold greater at Tittabawassee River SAs than RAs, respectively, while concentrations at Saginaw River SAs were intermediate. Mean concentrations of $\Sigma$ PCDD/DFs and TEQswHO-Avian in primarily terrestrial orders were $<1$ - to 29 -fold and 7 - to 220-fold greater at Tittabawassee River SAs than RAs, respectively, while concentrations at Saginaw River SAs were intermediate. Concentrations of $\Sigma \mathrm{PCDD} / \mathrm{DFs}$ in the primarily aquatic invertebrate orders of Trichoptera and Nematocera were significantly greater at SAs $(F=75.76, p<0.0001$ and $F=10.74, p=$ 0.0055 , respectively) compared to RAs, while concentrations in Ephemeroptera were similar. One Ephemeroptera sample from R-1 was greater than the rest with a $\Sigma \mathrm{PCDD} / \mathrm{DF}$ concentration of $2.5 \times 10^{3} \mathrm{ng} / \mathrm{kg}$ ww. However, this difference from other samples was no longer apparent when the 
sample contaminant concentration was reported as $\Sigma$ TEQs WHO-Avian $_{\text {(3.0 }} \times 10^{1} \mathrm{ng} / \mathrm{kg} \quad$ ww $)$. Concentrations of $\Sigma$ PCDD/DFs in the primarily terrestrial invertebrate orders of Brachycera, Lepidoptera, and Oligocheata were significantly greater at SAs $(F=5.66, p=0.0447, F=17.63$, $p=0.0005$, and $F=200.53, p<0.0001$, respectively) compared to RAs, while concentrations in Araneae and Orthoptera were similar. Concentrations of TEQswHO-Avian for all invertebrate orders that were predominant in the diets were significantly greater at SAs compared to RAs. Maximum concentrations of TEQs WHO-Avian ranged from $2.3 \times 10^{1} \mathrm{ng} / \mathrm{kg}$ ww at $\mathrm{T}-3$ in Nematocera to $1.4 \times 10^{3} \mathrm{ng} / \mathrm{kg}$ ww at $\mathrm{T}-3$ in Oligocheata (additional descriptive statistics are presented for predominant orders by site in Electronic supplementary material, Tables 3 to 10).

Minimum, mean, and median concentrations of TEQswHO-Avian followed a similar trend as $\Sigma$ PCDD/DFs for all species. Mean concentrations of TEQs ${ }_{W H O}$-Avian in food web-based dietary estimates for house wrens, tree swallows, and eastern bluebirds were 53-, 40-, and 72-fold greater at Tittabawassee River SAs than RAs, respectively. The maximum concentration of TEQswHO-Avian in food web-based dietary estimates for house wrens, tree swallows, and eastern bluebirds were $1.6 \times 10^{2}, 7.6 \times 10^{2}$, and $2.3 \times 10^{2} \mathrm{ng} / \mathrm{kg} \mathrm{ww}$, respectively.

Concentrations of $\Sigma$ PCDD/DFs and

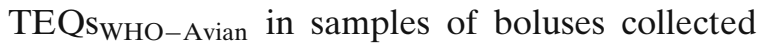
from nestling house wrens, tree swallows, and eastern bluebirds were greater at Tittabawassee River SAs compared to RAs. Mean concentrations of $\Sigma$ PCDD/DFs and TEQswHO-Avian in boluses collected from nestlings from all three species ranged from 6- to 21-fold and 41- to 136-fold greater at Tittabawassee River SAs than RAs, respectively. The maximum concentrations of TEQSWHO-Avian in bolus samples collected from nestling house wrens, tree swallows, and eastern bluebirds occurred at T-6 and were $4.7 \times 10^{2}, 9.5 \times 10^{2}$, and $5.7 \times 10^{2} \mathrm{ng} / \mathrm{kg} \mathrm{ww}$, respectively.

Concentrations of $\Sigma$ PCDD/DFs in food webbased dietary estimates varied by species when compared to bolus-based dietary estimates. Mean and median concentrations of $\Sigma \mathrm{PCDD} / \mathrm{DFs}$ in food web-based dietary estimates were greater for tree swallows (1.7- and 3.1-fold, respectively), similar for eastern bluebirds, and lesser for house wrens (2.0- and 1.7-fold, respectively) compared to those in bolus-based dietary estimates (Fig. 3).

Relative proportions of mean PCDD/DF concentrations contributed by individual congeners for invertebrates collected during food web sampling varied among sampling areas and among individual invertebrate orders. At RAs, mean PCDD/DF congener profiles for invertebrates were dominated by $51 \%$ to $78 \% 1,2,3,4$, $6,7,8,9$-octachlorodibenzo- $p$-dioxin compared to SAs that only contained $19 \%$ to $47 \%$. Mean PCDD/DF congener profiles for Trichoptera, Nematocera, Ephemeroptera, and Brachycera were dominated by 2,3,7,8-TCDF at Tittabawassee River SAs, while Oligocheata averaged only $14 \%$

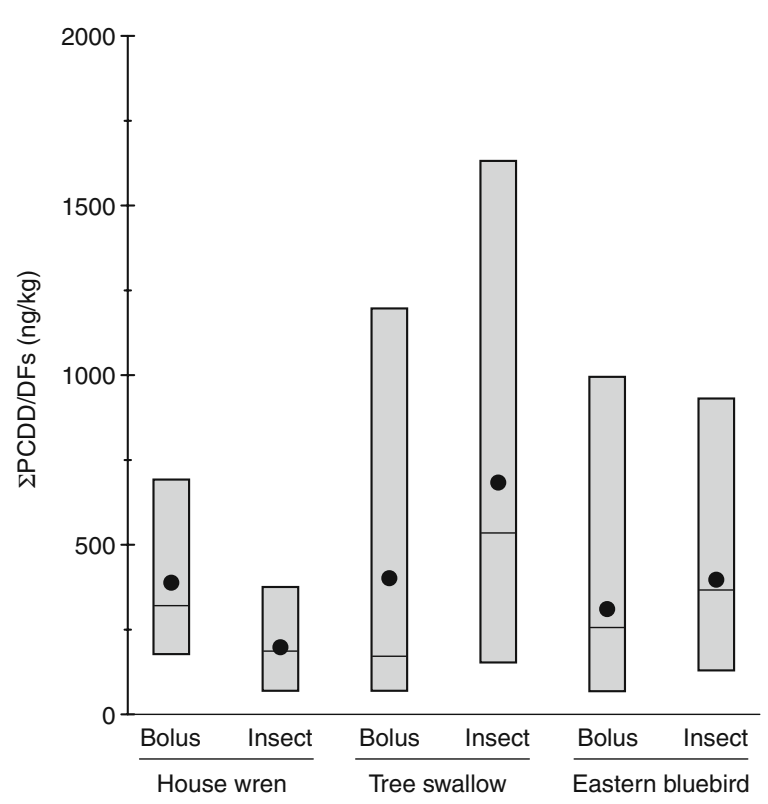

Fig. 3 Comparison of ranges, median, and mean $\Sigma$ PCDD/DF concentrations ( $\mathrm{ng} / \mathrm{kg} \mathrm{ww}$ ) of site-specific bolus-based (Bolus) and food web-based (Insect) dietary exposure estimates for house wren, tree swallow, and eastern bluebird diets collected in 2004-2006 at Tittabawassee River study areas (T-3 to T-6) downstream of Midland, Michigan, USA. Insect was calculated from composite samples of invertebrates from food web collections weighted by dietary composition. Bars indicate ranges; dots indicate means; and dashes indicate median values 
2,3,7,8-TCDF (Fig. 4). Five congeners contributed $77 \%$ to $90 \%$ of relative proportions of PCDD/DF congener concentrations in bolus-based and food web-based dietary estimates at both RAs and SAs. Relative proportions of PCDD/DF concentrations contributed by TCDF were $17 \%$ and $14 \%$ less for food web-based dietary estimates compared to bolus-based estimates for tree swallows and eastern bluebirds, respectively, while house wren proportions were similar. Relative proportions of $\mathrm{PCDD} / \mathrm{DF}$ concentrations in bolus samples for all species varied by site, with T-6 generally having $20 \%$ greater $2,3,7,8$-TCDF than other Tittabawassee River SAs (Fig. 5).
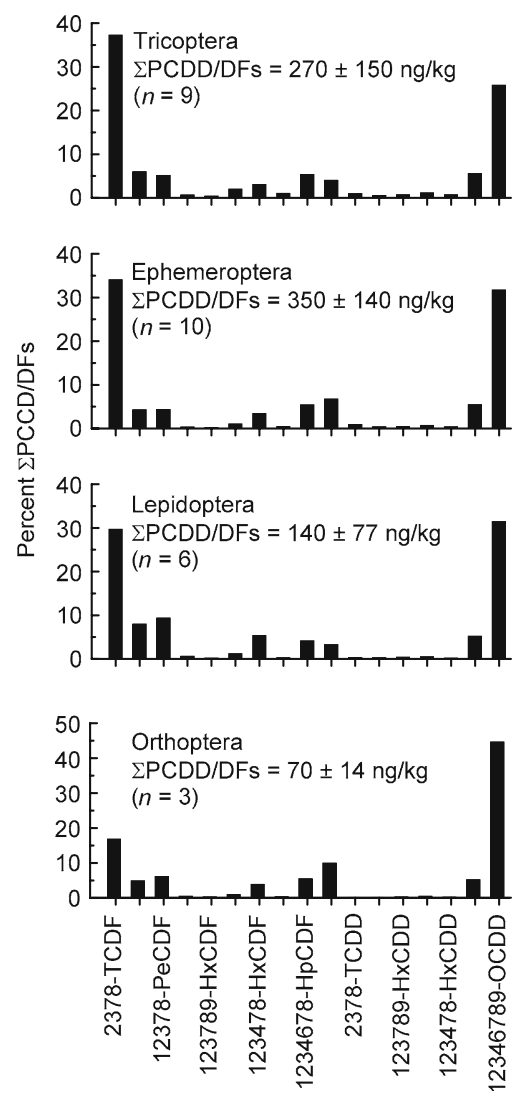

Fig. 4 Mean percent $\Sigma$ PCDD/DF congener profiles for predominant dietary aquatic and terrestrial invertebrate orders for house wrens, tree swallows, and eastern bluebirds collected during 2004 at Tittabawassee River study areas (T-3 to T-6) downstream of Midland, Michigan, USA. Mean \pm SD $\Sigma$ PCDD/DF concentrations presented by order; scale on the $y$-axis varies. Sample size indicates number of composite invertebrate samples
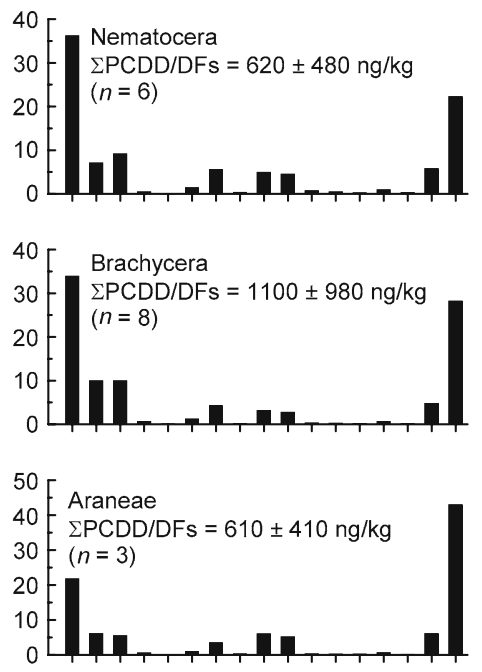

Potential average daily dose

$\mathrm{ADD}_{\text {pot }}$ for adult house wrens, tree swallows, and eastern bluebirds were greater at SAs compared to RAs when based on either bolus sample concentrations or food web-based concentrations for both $\Sigma \mathrm{PCDD} / \mathrm{DFs}$ and TEQswHO-Avian. $\mathrm{ADD}_{\text {pot }}$ based on bolus sample concentrations of $\Sigma$ PCDD/DFs and TEQswHO-Avian for adult house wrens, tree swallows, and eastern bluebirds were 14- and 136-fold, 6- and 41-fold, and 21- and 125-fold greater at Tittabawassee River SAs than RAs, respectively (Table 1). $\mathrm{ADD}_{\text {pot }}$ based on food web-based concentrations of $\Sigma \mathrm{PCDD} / \mathrm{DFs}$

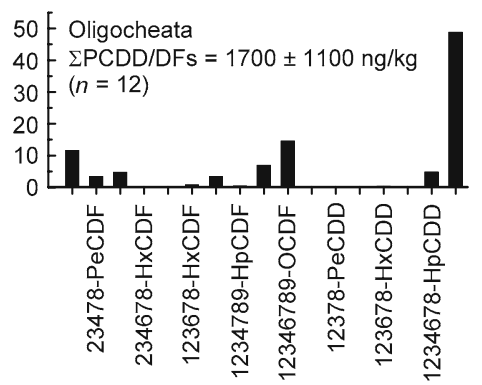

from food web collections. TCDF tetrachlorodibenzofuran, $P e C D F$ pentachlorodibenzofuran, $H x C D F$ hexachlorodibenzofuran, HpiCDF heptachlorodibenzofuran, $O C D F$ octachlorodibenzofuran, TCDD tetrachlorodibenzo- $p$-dioxin, $P e C D D$ pentachlorodibenzo- $p$-dioxin, $H x C D D$ hexachlorodibenzo- $p$-dioxin, $H p C D D$ heptachlorodibenzo- $p$-dioxin, $O C D D$ octachlorodibenzop-dioxin 
Fig. 5 Mean percent $\Sigma$ PCDD/DF congener profiles for dominant congeners in nestling house wren (a), tree swallow (b), and eastern bluebird (c) bolus samples by site collected from the Chippewa and Tittabawassee Rivers floodplains in 2004-2007, Midland, Michigan, USA. 2378tetrachlorodibenzofuran (black); 23478-

pentachlorodibenzofuran (angled stripe); 12378pentachlorodibenzofuran (dark gray); $1234678-$ heptachlorodibenzo- $p$ dioxin (horizontal stripe); 12346789-

octachlorodibenzo- $p$ dioxin (light gray); $n=1$ for house wren at R-1 and tree swallow at T-5; $n=3$ for eastern bluebird at T-3 and T-6; $n=4$ for tree swallow at R-2; and $n=2$ for all other sites
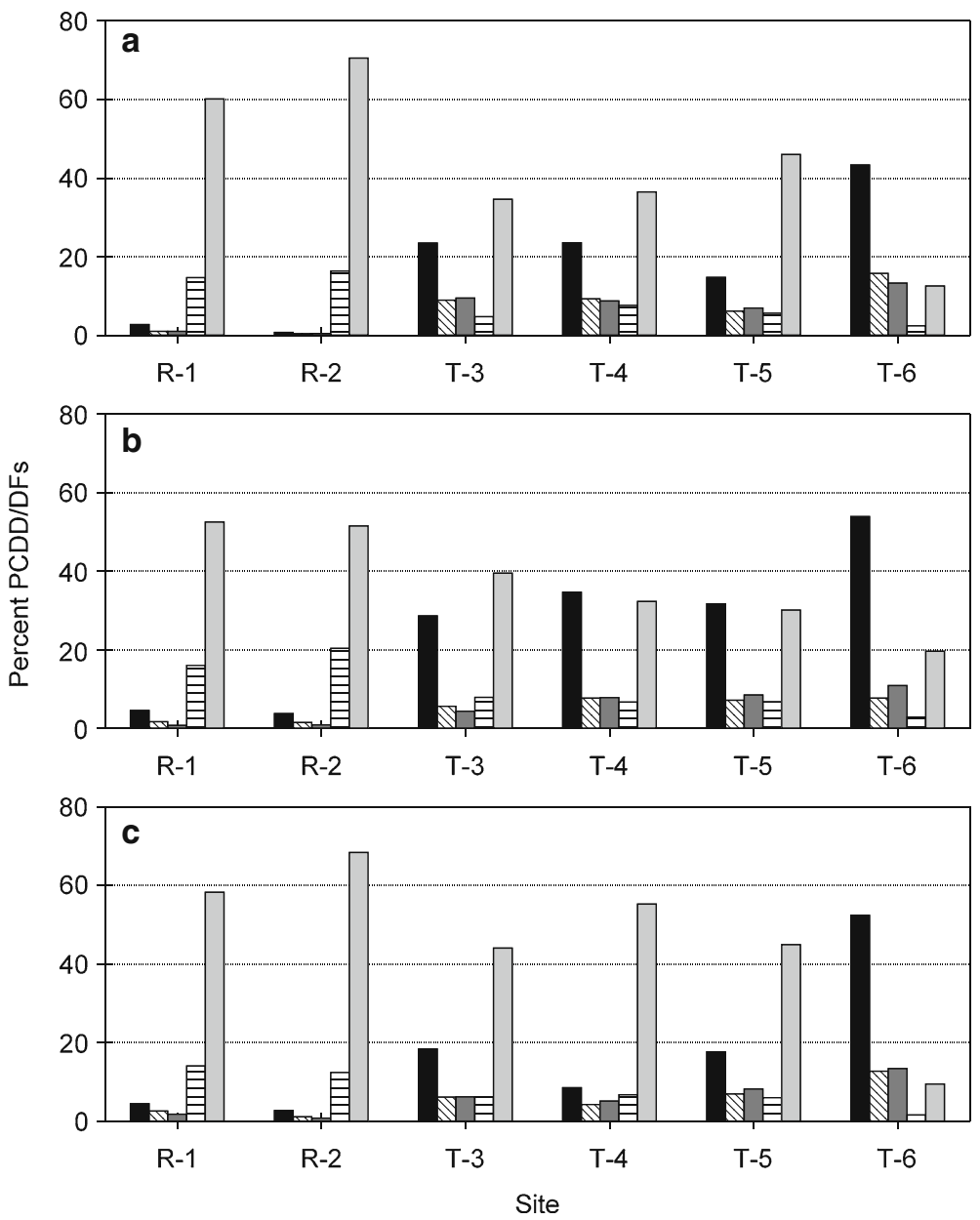

or TEQswHO-Avian for adult house wrens, tree swallows, and eastern bluebirds were 5- and 45fold, 5- and 41-fold, and 9- and 70-fold greater at the Tittabawassee River SAs than RAs, respectively (Table 1). ADD pot based on food web-based concentrations of $\Sigma$ PCDD/DFs and TEQswHO-Avian for adults of all studied species were less for Saginaw River SAs compared to Tittabawassee River SAs (Table 1). ADD pot ranges for concentrations of both $\Sigma \mathrm{PCDD} / \mathrm{DFs}$ and TEQswHO-Avian overlapped for adult tree swallows based either on bolus-based or food webbased dietary concentrations, whereas $\mathrm{ADD}_{\text {pot }}$ ranges were greater for bolus-based compared to food web-based dietary concentrations for both house wren and eastern bluebird adults (Table 1).
Total predicted residue concentrations in nestlings

Total predicted concentrations of $\Sigma \mathrm{PCDD} / \mathrm{DFs}$ and TEQswHO-Avian in nestling house wrens, tree swallows, and eastern bluebirds were greater at SAs compared to RAs for either bolus-based or food web-based diets. Average predicted concentrations of $\Sigma$ PCDD/DFs and TEQswHO-Avian for bolus-based diets in nestling house wrens, tree swallows, and eastern bluebirds were 14- and 100fold, 6- and 28-fold, and 20- and 94-fold greater at Tittabawassee River SAs than RAs, respectively (Table 2). Average predicted concentrations of $\Sigma \mathrm{PCDD} / \mathrm{DFs}$ and TEQswHO-Avian for food web-based diets in nestling house wrens, tree 
swallows, and eastern bluebirds were 6- and 44fold, 4- and 28-fold, and 9- and 60-fold greater at Tittabawassee River SAs than RAs, respectively (Table 2). Ranges of predicted concentrations of $\Sigma$ PCDD/DFs and TEQswHO-Avian in nestlings of all species were comparable between bolus-based or food web-based dietary exposures (Table 2).

Predictions of nestling body burdens ( $\Sigma$ PCDD/DFs) at fledge based on bolus $\mathrm{ADD}_{\text {pot }}$ were greater than those measured (Fredricks et al. 2010a) for all species studied regardless of study area. Nestling body burdens equaled the sum of the total ingestion of bolus-based dietary $\Sigma$ PCDD/DFs over the nesting period and measured average total $\Sigma$ PCDD/DFs per egg divided by the average nestling mass (Fredricks et al. 2010b). Mean $\pm \mathrm{SD}$ total picograms $\Sigma$ PCDD/DFs per egg of house wren, tree swallow, and eastern bluebird eggs was $1.2 \times 10^{2} \pm$ $7.8 \times 10^{1}(n=12), 1.3 \times 10^{3} \pm 7.6 \times 10^{2}(n=14)$, and $2.8 \times 10^{2} \pm 2.2 \times 10^{2}(n=12)$ in the RAs and $2.2 \times 10^{3} \pm 1.4 \times 10^{3}(n=21), 1.9 \times 10^{3} \pm$ $1.6 \times 10^{3}(n=28)$, and $8.7 \times 10^{2} \pm 3.9 \times 10^{2}$ $(n=23)$ in the SAs, respectively (Fredricks et al.
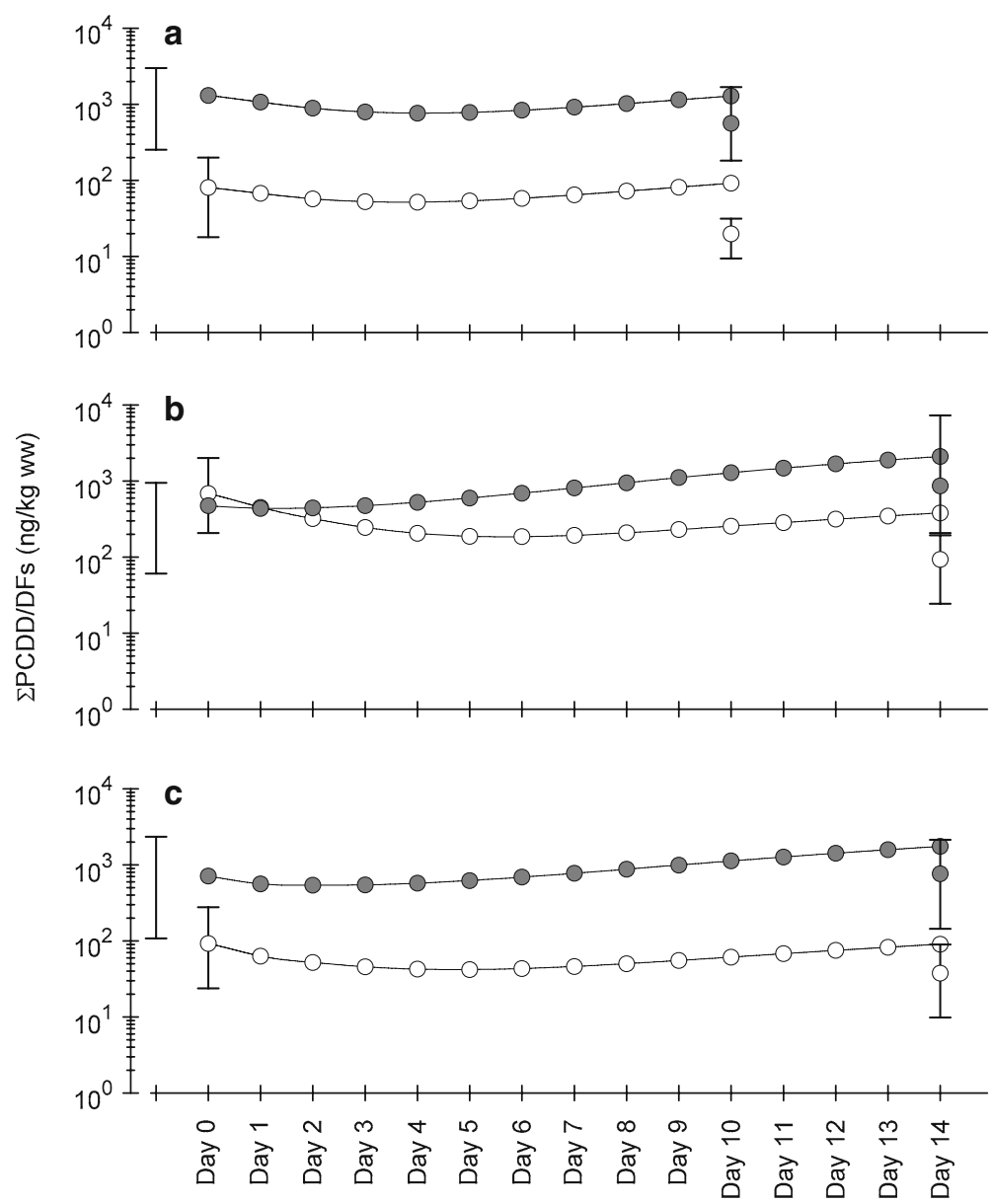

Fig. 6 Predicted nestling body burdens based on adjusted dietary accumulation of $\Sigma \mathrm{PCDD} / \mathrm{DFs}$ from mean bolus-based concentrations and food intake equations (line connected points) and measured mean with range of concentrations in eggs and nestlings (floating points) for house wrens (a), tree swallows (b), and eastern bluebirds (c) collected in the Chippewa and Tittabawassee River floodplains during 2004-2007 near Midland, Michigan, USA. Predicted nestling body burdens were adjusted based on 0.7 assimilation efficiency (Nichols et al. 2004). Open symbols are from reference areas (R-1 and R-2); closed symbols are from Tittabawassee River study areas (T-3 to T-6); egg concentration ranges from Tittabawassee River study areas are offset to the left 
2010a). Mean \pm SD concentration (nanograms per kilogram ww) of $\Sigma$ PCDD/DFs in nestlings of house wrens, tree swallows, and eastern bluebirds at reference areas and Tittabawassee River SAs was $2.0 \times 10^{1} \pm 7.5 \times 10^{0}(n=12)$ and $5.6 \times 10^{2} \pm 4.0 \times 10^{2} \quad(n=26), \quad 9.4 \times$ $10^{1} \pm 4.9 \times 10^{1}(n=12)$ and $8.7 \times 10^{2} \pm 1.5 \times 10^{3}$ $(n=21)$, and $3.8 \times 10^{1} \pm 2.4 \times 10^{1} \quad(n=12)$ and $7.6 \times 10^{2} \pm 5.7 \times 10^{2}(n=16)$, respectively (Fredricks et al. 2010a). Maternal transfer of total $\Sigma$ PCDD/DFs per egg contributed $<15 \%$ of the predicted nestling body burdens at fledge for all species studied regardless of study area or diet type, with the exception of the house wren food web-based exposure where maternal transfer contributed approximately 25\%. Therefore, predictions of nestling body burdens (Fig. 6) were largely determined by dietary ingestion of $\Sigma$ PCDD/DFs and selection of dietary exposure estimates.

\section{Discussion}

Dietary composition

Passerines have a limited foraging range when feeding nestlings (Pinkowski 1977; Quinney and Ankney 1985) and preferentially may select the most beneficial invertebrates rather than the most abundant (Guinan and Sealy 1987; McCarty and Winkler 1999; Quinney and Ankney 1985). Prey selection also depends on the age of the nestlings (Luttenton 1989; Morton 1984), with smaller invertebrates with less chitin and relatively higher caloric content selected which facilitates digestion and growth of younger nestlings (Pinkowski 1978).

Bolus sampling was initiated 3-4 days posthatch, which possibly limited the presence of some orders from our analyses. Additionally, incidental soil and sediment ingestion were not considered for dietary exposure for several reasons: (1) deionized water-rinsed non-depurated Oligocheata were used and likely represent the most probable source of soil exposure; (2) fieldcollected invertebrates were not rinsed prior to analyses so any incidental soil or sediment would be included in their analyses; (3) concentrations of $\Sigma$ PCDD/DF in soil and sediment were greater than those in invertebrates and even small percentages could skew estimated dietary exposures; and (4) PCDD/DFs are less bioavailable when bound to soil or sediment and are likely not assimilated to the same degree as in biota (Alexander 2000; Budinsky et al. 2008; Froese et al. 1998; Stephens et al. 1995).

Dietary items collected in site-specific bolus samples from nestling house wrens, tree swallows, and eastern bluebirds represented similar orders as expected from literature-based diets, while relative proportions of invertebrate orders varied. When feasible, it is important to quantify site-specific dietary composition since variations in prey selection can influence dietary exposure estimates (Neigh et al. 2006a; Papp et al. 2007; Smits et al. 2005). Literature-based estimates of tree swallow ingestion of Dipterans were 15-20\% (ww; Johnson and Lombardo 2000; McCarty and Winkler 1999; Neigh et al. 2006a) compared to $52 \%$ in the current study. Nestling eastern bluebirds from this study were fed primarily Orthoptera (44\% ww) and Lepidoptera (28\% ww), while nestlings from other studies in Michigan were fed primarily Orthoptera (45\% ww) and Trichoptera (30\% ww; Neigh et al. 2006a), and Lepidoptera (40\% ww), Orthoptera (20\% ww), and Oligocheata (20\% ww; Pinkowski 1978). Similar numbers of Lepidoptera larvae and adults were fed to house wren nestlings $(52 \%)$ compared to nestlings in Ohio (57\%; Luttenton 1989), but were greater than numbers fed to house wren nestlings in Illinois (22\%; Morton 1984) and Michigan (30\%; Neigh et al. 2006a). However, despite the lesser frequency of Lepidoptera in the Michigan study, the order still accounted for approximately $80 \%$ of the diet by mass (Neigh et al. 2006a).

There was a greater prevalence of Trichoptera in the diet of tree swallows at upstream RAs compared to downstream SAs. Although Trichoptera abundance was not quantified at study sites; tree swallow foraging and dietary composition is related to prey abundance (McCarty 1997). Therefore, the lower Trichoptera abundance at SAs was likely due to site-specific habitat and river flow differences. Trichoptera depend on suitable riverbed substratum for attachment (Wiggins 1996), and downstream SA substrata are dominated by a sandy bottom with limited submerged 
vegetation or debris. Additionally, greater sedimentation and poorer water quality at SAs could also influence the presence of Trichoptera since they are considered a sensitive order to these types of disturbance (Hachmöller et al. 1991).

Eastern bluebird foraging on Oligocheata was primarily limited to T-4 in both 2005 and 2006. Similar habitat characteristics and rainfall patterns were present in the vicinity of nest boxes at other sites in both the RAs and SAs. Pair/individual feeding specialization did not appear to be a factor as different adult pairs bred at T-4 between years. It is possible that soil conditions at T-4 contributed to greater Oligocheata presence than at other sites, but specific measurements were not made. A similar pattern of hitor-miss Oligocheata foraging by eastern bluebirds has been observed in other Michigan studies. On the Kalamazoo River, Oligocheata were not collected in bolus samples from nestling eastern bluebirds (Neigh et al. 2006a), but were identified in adult feeding trips and bolus samples from eastern bluebirds in Macomb County (Pinkowski 1978). In the current study, adult eastern bluebirds that fed Oligocheata to nestlings did so early in the nesting season, and Oligocheata were limited to the first brood, which was similar to observations in previous research (Pinkowski 1978).

\section{$\Sigma$ PCDD/DFs and TEQswHO-Avian}

Concentrations of $\Sigma$ PCDD/DF and TEQswHO-Avian varied among invertebrate orders at Tittabawassee River SAs. Since food web-based invertebrate samples represented composite samples of multiple individuals, there was likely some small-scale spatial integration due to movement of invertebrates into the sampling grids from nearby areas. General relationships at SAs indicated some large-scale spatial trends. Invertebrates at T- 6 consistently contained maximum concentrations as compared to other SAs.

Habitat use by invertebrates also resulted in concentration differences between and within orders. Of the predominant invertebrate orders that made up the majority of the dietary composition for all three study species, terrestrial orders had the greatest concentrations (Brachycera and Oligocheata). Within one order, terrestrial
Dipterans (Brachycera) had two times greater $\Sigma$ PCDD/DF concentrations and TEQs ${ }_{W H O-A v i a n}$ than aquatic Dipterans (Nematocera) at SAs. Concentrations in Lepidoptera and Orthoptera, major contributors to both house wren and eastern bluebird diets ( $72 \%$ for both), were the least of all the predominant orders. Sex-specific differences within invertebrate orders were beyond the scope of our research, but Maul et al. (2006) separated the genus Chironomus from other Nematocerans and analyzed the sexes separately for PCB concentrations. Male Chironomus had greater concentrations compared to females, and differences were attributed to sex-dependent life history factors. It is likely that similar subtle differences in order-specific life history factors can influence exposure and assimilation of PCDD/DFs.

Similar to individual invertebrate orders, bolus samples collected from all species had greatest residue concentrations at T-6. Additionally, relative proportions of mean 2,3,7,8-TCDF concentrations in bolus samples were greatest at T-6 for all study species. The relative proportion of 2,3,7,8-TCDF increases in bolus samples from $\mathrm{T}-3$ to $\mathrm{T}-6$, which mirrors the pattern of increasing $\Sigma$ PCDD/DF concentrations in bolus samples (Fig. 5). These trends are similar to house wren, tree swallow, and eastern bluebird tissues collected from the same sites (Fredricks et al. 2010a). One possible explanation for greater values in both food web items and bolus samples at the T6 location involves the natural hydrology of the Tittabawassee River. When at flood stage, the river flows across the large bends near T-6 instead of following the normal river channel (Fig. 1). The water loses momentum and energy quickly and deposits large amounts of sediment over those areas, creating a "sink" location for sediment-bound contaminants.

Food web dietary exposure estimates were based on site-specific dietary composition, derived from bolus sample composition, combined with concentrations in respective invertebrate orders. While ranges of $\Sigma$ PCDD/DF concentrations (Fig. 3) and TEQswHO-Avian estimated dietary exposure varied among species, similar concentration trends were present between $\Sigma$ PCDD/

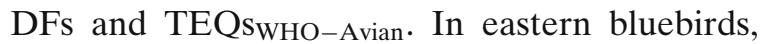


however, the lesser TEQ ${ }_{\mathrm{WHO}-\text { Avian }}$ concentrations in Orthoptera and Oligocheata (Fig. 4) resulted in lesser food web-based dietary TEQswHO-Avian than the $\Sigma \mathrm{PCDD} / \mathrm{DF}$ concentrations would suggest due to the relatively low TCDD potency associated with these orders. Approximately $50 \%$ of the $\Sigma$ PCDD/DF concentrations in eastern bluebird food web-based dietary exposure estimates were from Oligocheata, which only occurred in a few nests at T-4. The presence of Oligocheata explains the difference between $\Sigma$ PCDD/DF concentrations and TEQs WHO-Avian $_{\text {food web-based }}$ dietary exposure estimates.

For house wrens and eastern bluebirds, the range of food web-based dietary exposure estimates was less than the exposure estimates based on bolus samples, while tree swallows had similar ranges. Species-specific foraging strategies between tree swallows and the terrestrial foraging species, combined with sampling protocols for food web collections, can account for this difference. Tree swallows primarily forage near or over bodies of water (McCarty 1997; McCarty and Winkler 1999), while house wrens and eastern bluebirds forage in close proximity to their nest box (Guinan and Sealy 1987; Pinkowski 1977). Since food web collections occurred in one location $(30 \times 30 \mathrm{~m})$ per site adjacent to the river, it is unlikely that terrestrial foraging species would forage exclusively in the same area. Tree swallows, meanwhile, are drawn to the river to feed where, due to river dynamics, concentrations are expected to be more uniform. Differences in PCB concentration between dietary samples (bolus or gut contents) and site-specific invertebrate samples (collected with nets) have been previously documented for passerines (Echols et al. 2004; Maul et al. 2006; Smits et al. 2005).

Exposure to PCDFs and PCDDs on both a $\Sigma$ PCDD/DF and TEQ ${ }_{W H O-A v i a n}$ basis of food web invertebrates and bolus samples from the current study was similar to or greater than that from other sites contaminated with chlorinated hydrocarbons. Stomach contents from tree swallow nestlings and pipers from the Woonasquatucket River floodplain contained 71 to $219 \mathrm{ng} / \mathrm{kg}$ ww 2,3,7,8-TCDD (Custer et al. 2005), while samples from the primarily PCBcontaminated Housatonic River area (Custer et al. 2003) had only a few PCDD/DF congeners with detectable concentrations (2,3,7,8-TCDF, 17-38 ng/kg ww; 1,2,3,7,8-pentachlordibenzofuran (PeCDF), 15-142 ng/kg ww; 1,2,3,4,6,7,8heptachlorodibenzofuran, $14-30 \mathrm{ng} / \mathrm{kg} \mathrm{ww})$. Tree swallows primarily exposed to PCBs in southern Illinois had dietary $\mathrm{TEQ}_{\mathrm{WHO}-\text { Avian }}$ concentrations that ranged from 0.52 to $35 \mathrm{ng} / \mathrm{kg}$ ww for food web samples and averaged $4.4 \mathrm{ng} / \mathrm{kg}$ ww in stomach contents (Maul et al. 2006).

Average potential daily dose

To gauge exposure and facilitate future assessment of reproductive risks, $\mathrm{ADD}_{\text {pot }}$ was estimated for adult passerines while breeding on-site. The $\mathrm{TEQ}_{\mathrm{WHO}-\mathrm{Avian}}$ dietary exposures reported here for the Tittabawassee River are similar to $\mathrm{TEQ} \mathrm{WHO}_{\mathrm{W}}$-Avian dietary exposure estimates reported for insectivorous passerines from the PCBcontaminated Kalamazoo River, Michigan, USA (Neigh et al. 2006a). Adult tree swallows (Kay et al. 2005) and house wrens (Blankenship et al. 2005 ) had $64 \%$ and $56 \%$ greater $\Sigma$ PCB body burdens, respectively, than nestlings from the same study sites on the Kalamazoo River. For the current study, adult passerines were not collected for residues analyses because of the concurrent long-term monitoring study of adult and nestling survival; however, based on the study from the Kalamazoo River, greater adult body burdens would be expected. The relative proportion of $\Sigma$ PCDD/DF to TEQ ${ }_{\text {WHO-Avian }}$ for adult $\mathrm{ADD}_{\text {pot }}$ for bolus-based and food web-based dietary exposures ranged from $4.2 \%$ to $9.2 \%$ and $2.0 \%$ to $3.2 \%$ at RAs, respectively, while at SAs, they ranged from $42 \%$ to $59 \%$ and $20 \%$ to $38 \%$, respectively. Greater percentages at SAs are due to greater proportions of primarily 2,3,7,8-TCDF and secondarily $2,3,4,7,8-\mathrm{PeCDF}$ in the congener profiles at those sites.

Total predicted residue concentrations in nestlings

Predicted nestling body burdens of PCDD/DFs prior to fledge were greater than measured mean nestling tissue concentrations (Fredricks et al. 2010a) regardless of study area. The most 
plausible explanations for this discrepancy are overestimates of the daily dietary exposures, overestimates of residue assimilation efficiency, or both. The predicted total ingestion by nestlings was based on a mean daily dietary dose that was calculated using residue concentrations in bolus samples. The bolus sample method was selected because bolus samples were composed of the invertebrates selected by the adult passerines onsite. When minimum values for bolus samples were used, instead of mean values, to estimate nestling body burdens at Tittabawassee River SAs, the predicted values were similar to the measured mean nestling tissue concentrations.

The second and more likely explanation of the overestimation of predicted nestling body burdens from bolus-based exposure estimates is that the assimilation efficiency for the sitespecific mixture of $\mathrm{PCDD} / \mathrm{DFs}$ is less than the 0.7 suggested for PCBs (Nichols et al. 2004). Differential metabolism of residues by embryos and nestlings or selective sequestration of specific PCDD/DF congeners could account for some of the difference between the predicted nestling body burdens from bolus-based exposure estimates and those measured in nestlings. The fact that house wren and eastern bluebird nestlings contained lesser percentages of 2,3,7,8-TCDF and greater percentages of 2,3,4,7,8-PeCDF compared to dietary exposure estimates suggests a dynamic metabolism or sequestration mechanism. Similarly, related field and laboratory studies have noted a short half-life for 2,3,7,8-TCDF in developing embryos and growing chicks that resulted in significantly lesser tissue concentrations than would have been expected (Zwiernik, unpublished data). Based on comparisons of congenerspecific adult biomagnification factors in herring gulls (Larus argentatus), TCDF was determined to be rapidly metabolized as opposed to $2,3,4,7,8$ PeCDF in which metabolism was determined to be variable and possibly linked to speciesspecific differences in distribution or metabolism (Braune and Norstrom 1989). Previous research on mallards (Anas platyrhynchos; Norstrom et al. 1976) and bald eagles (Haliaeetus leucocephalus; Elliott et al. 1996) have discussed similar trends in metabolism for PCDF congeners. Alternatively, the predicted $\mathrm{PCB}$ concentrations based on the diet and those measured in tree swallow nestlings along the Saginaw River, Michigan were similar based on the assimilation efficiency of 0.7 (Echols et al. 2004). Those authors suggested that differential metabolism of PCBs was not very important in nestlings. Potential explanations for the differences between house wren and eastern bluebird nestlings and dietary exposure estimates could be unique PCDD/DF bioavailability from terrestrial invertebrates. However, these adjustments still cannot fully explain the differences observed between expected and observed concentrations in nestlings.

\section{Conclusions}

Estimates of dietary exposure for both adult and nestling passerines were greater at Tittabawassee River SAs compared to RAs, while exposure at Saginaw River SAs was intermediate. Though few studies have investigated avian dietary exposure of PCDD/DFs based on TEQswHO-Avian, our results were in line with other contaminated sites. Estimates of the dietary exposure of nestlings were greater than the measured concentrations of $\Sigma$ PCDD/DF in nestlings (Fredricks et al. 2010a). A combination of (1) metabolism of compounds prior to hatch, (2) possible overestimation of food intake rates, (3) positively skewed concentration data in the diet at SAs, and (4) assimilation of $<70 \%$ of the compounds from the diet likely led to greater predicted concentrations relative to measured concentrations in nestlings. Characterizing dietary exposure for passerine birds with either bolus-based sample analyses or food webbased dietary analyses involves labor-intensive sampling procedures. Our results indicate that both methods provide similar exposure estimates that varied by species. Due to efficient bolus collection via cable ties, collection of true sitespecific dietary items, and the time savings associated with not sorting collected invertebrates to order for analytical analyses, the authors recommend future dietary exposure assessments to use bolus sampling for passerines when feasible. Concurrent work has addressed implications of 
these results by incorporating data from tissue exposure (Fredricks et al. 2010a) and productivity (Fredricks et al. 2010b) into aquatic (Fredricks et al. 2010c) and terrestrial (Fredricks et al. 2010d) passerine risk assessments. The incorporation of three lines of evidence into multiple lines of evidence assessment of ecological risk (Fairbrother 2003) will provide site-specific information to make informed decisions about the potential impact(s) of contaminants and will aid in both the planning and evaluation of effective remedial actions.

Acknowledgements The authors thank all the staff and students of the Michigan State University-Aquatic Toxicology Laboratory (MSU-ATL) field crew and researchers at ENTRIX Inc., Okemos, Michigan for their dedicated assistance. Additionally, the authors recognize Michael J. Kramer and Nozomi Ikeda for their assistance in the laboratory, James Dastyck and Steven Kahl of the US Fish and Wildlife Service Shiawassee National Wildlife Refuge for their assistance and access to the refuge property, the Saginaw County Park and Tittabawassee Township Park rangers for access to Tittabawassee Township Park and Freeland Festival Park, Tom Lenon and Dick Touvell of the Chippewa Nature Center for assistance and property access, and Michael Bishop of Alma College for his key contributions to our banding efforts as our Master Bander. The authors acknowledge the more than 50 cooperating landowners throughout the research area who granted us access to their property, which made this research possible. Prof. Giesy was supported by the Canada Research Chair program and an at-large Chair Professorship at the Department of Biology and Chemistry and Research Centre for Coastal Pollution and Conservation, City University of Hong Kong. Funding was provided through an unrestricted grant from The Dow Chemical Company, Midland, Michigan to J.P. Giesy and M.J. Zwiernik of Michigan State University. Portions of the research were supported by a Discovery Grant from the National Science and Engineering Research Council of Canada (Project \#32641507 ) and a grant from the Western Economic Diversification Canada (Project \#6578 and 6807).

Animal use All aspects of the study that involved the use of animals were conducted in the most humane way possible. To achieve that objective, all aspects of the study design were performed following standard operating procedures (Protocol for Monitoring and Collection of Box-Nesting Passerine Birds 03/04-045-00; Field studies in support of Tittabawassee River Ecological Risk Assessment 03/04-042-00) approved by Michigan State University's Institutional Animal Care and Use Committee (IACUC). All of the necessary state and federal approvals and permits (Michigan Department of Natural Resources Scientific Collection Permit SC1252, US Fish and Wildlife Migratory Bird Scientific Collection Permit MB102552-1, and subpermitted under US Department of the Interior Federal Banding Permit 22926) are on file at MSU-ATL.

Open Access This article is distributed under the terms of the Creative Commons Attribution Noncommercial License which permits any noncommercial use, distribution, and reproduction in any medium, provided the original author(s) and source are credited.

\section{References}

Alexander, M. (2000). Aging, bioavailability, and overestimation of risk from environmental pollutants. Environmental Science \& Technology, 34, 4259-4265.

Amendola, G. A., \& Barna, D. R. (1986). Dow chemical wastewater characterization study: Tittabawassee River sediments and native fish (pp. 1-118). EPA-905/4-88003.

Ankley, G. T., Niemi, G. J., Lodge, K. B., Harris, H. J., Beaver, D. L., Tillitt, D. E., et al. (1993). Uptake of planar polychlorinated biphenyls and 2,3,7,8-substituted polychlorinated dibenzofurans and dibenzo- $p$-dioxins by birds nesting in the lower Fox River and Green Bay, Wisconsin, USA. Archives of Environmental Contamination and Toxicology, 24, 332-344.

ATS (2007). Remedial Investigation Work Plan, Tittabawassee River and Floodplain Soils, Midland, Michigan, December 2006; revised September 2007. Ann Arbor Technical Services, Inc.

ATS (2009). Final GeoMorph® Site Characterization Report, Tittabawassee River and Floodplain Soils, Volume II of VI-Evaluation of Constituents of Interest, Supplemental Information, Midland, Michigan, June 2009. Ann Arbor Technical Services, Inc.

Beal, F. E. L. (1915). Food of the robins and bluebirds of the United States. Bulletin of the U.S. Department of Agriculture, 171, 1-31.

Bishop, C. A., Koster, M. D., Chek, A. A., Hussell, D. J. T., \& Jock, K. (1995). Chlorinated hydrocarbons and mercury in sediments, red-winged blackbirds (Agelaius phoeniceus) and tree swallows (Tachycineta bicolor) from wetlands in the Great Lakes-St. Lawrence River basin. Environmental Toxicology and Chemistry, 14, 491-501.

Blancher, P. J., \& McNicol, D. K. (1991). Tree swallow diet in relation to wetland acidity. Canadian Journal of Zoology, 69, 2629-2637.

Blankenship, A. L., Zwiernik, M. J., Coady, K. K., Kay, D. P., Newsted, J. L., Strause, K., et al. (2005). Differential accumulation of polychlorinated biphenyl congeners in the terrestrial food web of the Kalamazoo River superfund site, Michigan. Environmental Science \& Technology, 39, 5954-5963.

Braune, B. M., \& Norstrom, R. J. (1989). Dynamics of organochlorine compounds in herring gulls: III. Tissue distribution and bioaccumulation in Lake Ontario 
gulls. Environmental Toxicology and Chemistry, 8, 957-968.

Budinsky, R. A., Rowlands, J. C., Casteel, S., Fent, G., Cushing, C. A., Newsted, J., et al. (2008). A pilot study of oral bioavailability of dioxins and furans from contaminated soils: Impact of differential hepatic enzyme activity and species differences. Chemosphere, 70, 1774-1786.

Custer, C. M., Custer, T. W., Allen, P. D., Stromborg, K. L., \& Melancon, M. J. (1998). Reproduction and environmental contamination in tree swallows nesting in the Fox River drainage and Green Bay, Wisconsin, USA. Environmental Toxicology and Chemistry, 17, 17861798.

Custer, C. M., Custer, T. W., Dummer, P. M., \& Munney, K. L. (2003). Exposure and effects of chemical contaminants on tree swallows nesting along the Housatonic River, Berkshire county, Massachusetts, USA, 19982000. Environmental Toxicology and Chemistry, 22, 1605-1621.

Custer, C. M., Custer, T. W., Rosiu, C. J., Melancon, M. J., Bickham, J. W., \& Matson, C. W. (2005). Exposure and effects of 2,3,7,8-tetrachlorodibenzo- $p$-dioxin in tree swallows (Tachycineta bicolor) nesting along the Woonasquatucket River, Rhode Island, USA. Environmental Toxicology and Chemistry, 24, 93-109.

Custer, C. M., \& Read, L. B. (2006). Polychlorinated biphenyl congener patterns in tree swallows (Tachycineta bicolor) nesting in the Housatonic River watershed, western Massachusetts, USA, using a novel statistical approach. Environmental Pollution, 142, 235-245.

Custer, T. W., Custer, C. M., Goatcher, B. L., Melancon, M. J., Matson, C. W., \& Bickham, J. W. (2006). Contaminant exposure of barn swallows nesting on Bayou D'Inde, Calcasieu Estuary, Louisiana, USA. Environmental Monitoring and Assessment, 121, 543-560.

Custer, T. W., Custer, C. M., \& Hines, R. K. (2002). Dioxins and congener-specific polychlorinated biphenyls in three avian species from the Wisconsin River, Wisconsin. Environmental Pollution, 119, 323-332.

Echols, K. R., Tillitt, D. E., Nichols, J. W., Secord, A. L., \& McCarty, J. P. (2004). Accumulation of PCB congeners in nestling tree swallows (Tachycineta bicolor) on the Hudson River, New York. Environmental Science \& Technology, 38, 6240-6246.

Eisler, R. (2000). Handbook of chemical risk assessment (Vol. 2). Boca Raton: Lewis.

Elliott, J. E., Norstrom, R. J., Lorenzen, A., Hart, L. E., Philibert, H., Kennedy, S. W., et al. (1996). Biological effects of polychlorinated dibenzo- $p$-dioxins, dibenzofurans, and biphenyls in bald eagle (Haliaeetus leucocephalus) chicks. Environmental Toxicology and Chemistry, 15, 782-793.

Fairbrother, A. (2003). Lines of evidence in wildlife risk assessments. Human and Ecological Risk Assessment, 9, 1475-1491.

Fredricks, T. B., Zwiernik, M. J., Seston, R. M., Coefield, S. J., Plautz, S. C., Tazelaar, D. L., et al. (2010a). Passerine exposure to primarily PCDFs and PCDDs in the river floodplains near Midland, Michigan, USA. Archives of Environmental Contamination and Toxicology (in press).

Fredricks, T. B., Zwiernik, M. J., Seston, R. M., Coefield, S. J., Stieler, C. N., Tazelaar, D. L., et al. (2010b). Reproductive success of house wrens, tree swallows, and eastern bluebirds exposed to primarily PCDFs in a river system downstream of Midland, Michigan, USA. Environmental Toxicology Chemistry (in press).

Fredricks, T. B., Zwiernik, M. J., Seston, R. M., Coefield, S. J., Tazelaar, D. L., Roark, S. A., et al. (2010c). Multiple lines of evidence risk assessment of tree swallows exposed to PCDFs and PCDDs in the Tittabawassee River floodplain, Midland, Michigan, USA. Environmental Toxicology Chemistry (in press).

Fredricks, T. B., Giesy, J. P., Coefield, S. J., Seston, R. M., Tazelaar, D. L., Roark, S. A., et al. (2010d). Multiple lines of evidence risk assessment of terrestrial passerines exposed to PCDFs and PCDDs in the Tittabawassee River floodplain, Midland, Michigan, USA. Human and Ecological Risk Assessment (in press).

Froese, K. L., Verbrugge, D. A., Ankley, G. T., Niemi, G. J., Larsen, C. P., \& Giesy, J. P. (1998). Bioaccumulation of polychlorinated biphenyls from sediments to aquatic insects and tree swallow eggs and nestlings in Saginaw Bay, Michigan, USA. Environmental Toxicology and Chemistry, 17, 484-492.

Guinan, D. M., \& Sealy, S. G. (1987). Diet of house wrens (Troglodytes aedon) and the abundance of the invertebrate prey in the dune-ridge forest, Delta Marsh, Manitoba. Canadian Journal of Zoology, 65, 15871596.

Hachmöller, B., Matthews, R. A., \& Brakke, D. F. (1991). Effects of riparian community structure, sediment size, and water-quality on the macroinvertebrate communities in a small, suburban stream. Northwest Science, 65, 125-132.

Harris, M. L., \& Elliott, J. E. (2000). Reproductive success and chlorinated hydrocarbon contamination in tree swallows (Tachycineta bicolor) nesting along rivers receiving pulp and paper mill effluent discharges. Environmental Pollution, 110, 307-320.

Henning, M. H., Robinson, S. K., McKay, K. J., Sullivan, J. P., \& Bruckert, H. (2003). Productivity of American robins exposed to polychlorinated biphenyls, Housatonic River, Massachusetts, USA. Environmental Toxicology and Chemistry, 22, 27832788.

Hilscherova, K., Kannan, K., Nakata, H., Hanari, N., Yamashita, N., Bradley, P. W., et al. (2003). Polychlorinated dibenzo- $p$-dioxin and dibenzofuran concentration profiles in sediments and flood-plain soils of the Tittabawassee River, Michigan. Environmental Science and Technology, 37, 468-474.

Johnson, M. E., \& Lombardo, M. P. (2000). Nestling tree swallow (Tachycineta bicolor) diets in an upland old field in western Michigan. American Midland Naturalist, 144, 216-219.

Kay, D. P., Blankenship, A. L., Coady, K. K., Neigh, A. M., Zwiernik, M. J., Millsap, S. D., et al. (2005). 
Differential accumulation of polychlorinated biphenyl congeners in the aquatic food web at the Kalamazoo River superfund site, Michigan. Environmental Science \& Technology, 39, 5964-5974.

Luttenton, M. J. (1989). Sex differences in parental investment in house wrens (Troglodytes aedon). MS thesis, Bowling Green State, Ohio, USA.

Mandal, P. K. (2005). Dioxin: A review of its environmental effects and its aryl hydrocarbon receptor biology. Journal of Comparative Physiology B-Biochemical Systemic and Environmental Physiology, 175, 221-230.

Maul, J. D., Belden, J. B., Schwab, B. A., Whiles, M. R., Spears, B., Farris, J. L., et al. (2006). Bioaccumulation and trophic transfer of polychlorinated biphenyls by aquatic and terrestrial insects to tree swallows (Tachycineta bicolor). Environmental Toxicology and Chemistry, 25, 1017-1025.

McCarty, J. P. (1997). Aquatic community characteristics influence the foraging patterns of tree swallows. Condor, 99, 210-213.

McCarty, J. P. (2002). The number of visits to the nest by parents is an accurate measure of food delivered to nestlings in tree swallows. Journal of Field Ornithology, 73, 9-14.

McCarty, J. P., \& Winkler, D. W. (1991). Use of an artificial nestling for determining the diet of nestling tree swallows. Journal of Field Ornithology, 62, 211-217.

McCarty, J. P., \& Winkler, D. W. (1999). Foraging ecology and diet selectivity of tree swallows feeding nestlings. Condor, 101, 246-254.

Mellott, R. S., \& Woods, P. E. (1993). An improved ligature technique for dietary sampling in nestling birds. Journal of Field Ornithology, 64, 205-210.

Mengelkoch, J. M., Niemi, G. J., \& Regal, R. R. (2004). Diet of the nestling tree swallow. Condor, 106, 423429.

Merritt, R. W. \& Cummins, K. W. (1996). An introduction to the aquatic insects of North America (3rd ed.). Dubuque, Iowa: Kendall/Hunt.

Morton, C. A. (1984). An experimental study of parental investment in house wrens. MS thesis, Illinois State University, Illinois, USA.

Neigh, A. M., Zwiernik, M. J., Blankenship, A. L., Bradley, P. W., Kay, D. P., MacCarroll, M. A., et al. (2006a). Exposure and multiple lines of evidence assessment of risk for PCBs found in the diets of passerine birds at the Kalamazoo River Superfund Site, Michigan. $\mathrm{Hu}$ man and Ecological Risk Assessment, 12, 924-946.

Neigh, A. M., Zwiernik, M. J., Bradley, P. W., Kay, D. P., Jones, P. D., Holem, R. R., et al. (2006b). Accumulation of polychlorinated biphenyls from floodplain soils by passerine birds. Environmental Toxicology and Chemistry, 25, 1503-1511.

Neigh, A. M., Zwiernik, M. J., Bradley, P. W., Kay, D. P., Park, C. S., Jones, P. D., et al. (2006c). Tree swallow (Tachycineta bicolor) exposure to polychlorinated biphenyls at the Kalamazoo River Superfund site, Michigan, USA. Environmental Toxicology and Chemistry, 25, 428-437.

Nichols, J. W., Echols, K. R., Tillitt, D. E., Secord, A. L., \& McCarty, J. P. (2004). Bioenergetics-based modeling of individual PCB congeners in nestling tree swallows from two contaminated sites on the upper Hudson River, New York. Environmental Science \& Technology, 38, 6234-6239.

Nichols, J. W., Larsen, C. P., McDonald, M. E., Niemi, G. J., \& Ankley, G. T. (1995). Bioenergetics-based model for accumulation of polychlorinated biphenyls by nestling tree swallows, Tachycineta bicolor. Environmental Science and Technology, 29, 604-612.

Norstrom, R. J., Risebrough, R. W., \& Cartwright, D. J. (1976). Elimination of chlorinated dibenzofurans associated with polychlorinated biphenyls fed to mallards (Anas platyrhynchos). Toxicology and Applied Pharmacology, 37, 217-228.

Nosek, J. A., Craven, S. R., Sullivan, J. R., Olson, J. R., \& Peterson, R. E. (1992). Metabolism and disposition of 2,3,7,8-tetrachlorodibenzo- $p$-dioxin in ring-necked pheasant hens, chicks, and eggs. Journal of Toxicology and Environmental Health, 35, 153-164.

Papp, Z., Bortolotti, G. R., Sebastian, M., \& Smits, J. E. G. (2007). PCB congener profiles in nestling tree swallows and their insect prey. Archives of Environmental Contamination and Toxicology, 52, 257-263.

Pinkowski, B. C. (1977). Foraging behavior of the eastern bluebird. The Wilson Bulletin, 89, 404-414.

Pinkowski, B. C. (1978). Feeding of nesting and fledgling eastern bluebirds. The Wilson Bulletin, 90, 84-98.

Quinney, T. E., \& Ankney, C. D. (1985). Prey size selection by tree swallows. The Auk, 102, 245-250.

Russell, R. W., Gobas, F. A. P. C., \& Haffner, G. D. (1999). Role of chemical and ecological factors in trophic transfer of organic chemicals in aquatic food webs. Environmental Toxicology and Chemistry, 18, 12501257.

Secord, A. L., McCarty, J. P., Echols, K. R., Meadows, J. C., Gale, R. W., Tillitt, D. E., et al. (1999). Polychlorinated biphenyls and 2,3,7,8-tetrachlorodibenzo$p$-dioxin equivalents in tree swallows from the upper Hudson River, New York State, USA. Environmental Toxicology and Chemistry, 18, 2519-2525.

Shaw, G. G. (1983). Organochlorine pesticide and PCB residues in eggs and nestlings of tree swallows, Tachycineta bicolor, in central Alberta. Canadian Field Naturalist, 98, 258-260.

Smits, J. E. G., Bortolotti, G. R., Sebastian, M., \& Ciborowski, J. J. H. (2005). Spatial, temporal, and dietary determinants of organic contaminants in nestling tree swallows in Point Pelee National Park, Ontario, Canada. Environmental Toxicology and Chemistry, 24, 3159-3165.

Spears, B. L., Brown, M. W., \& Hester, C. M. (2008). Evaluation of polychlorinated biphenyl remediation at a superfund site using tree swallows (Tachycineta bicolor) as indicators. Environmental Toxicology and Chemistry, 27, 2512-2520.

Stephens, R. D., Petreas, M. X., \& Hayward, D. G. (1995). Biotransfer and bioaccumulation of dioxins and furans from soil: Chickens as a model for foraging animals. Science of the Total Environment, 175, 253-273.

US Environmental Protection Agency (USEPA) (1993). Wildlife exposure factors handbook volumes I II, and 
III. EPA/60/R-93/187B. Washington: US Environmental Protection Agency.

US Environmental Protection Agency (USEPA) (1998). Polychlorinated dibenzodioxins (PCDDs) and polychlorinated dibenzofurnas $(P C D F s)$ by high-resolution gas chromatography/high-resolution mass spectrometry (HRGC/HRMS). Revision 1. Method 8290A. $S W-846$. Washington: US Environmental Protection Agency.

van den Berg, M., Birnbaum, L., Bosveld, A. T. C., Brunstrom, B., Cook, P., Freeley, M., et al. (1998). Toxic equivalency factors (TEFs) for PCBs, PCDDs, PCDFs for humans and wildlife. Environmental Health Perspectives, 106, 775-792.
Wan, Y., Hu, J., Yang, M., An, L., An, W., Jin, X., et al. (2005). Characterization of trophic transfer for polychlorinated dibenzo- $p$-dioxins, dibenzofurans, non- and mono-ortho polychlorinated biphenyls in the marine foodweb of Bohai Bay, North China. Environmental Science \& Technology, 39, 2417-2425.

Wayland, M., Trudeau, S., Marchant, T., Parker, D., \& Hobson, K. A. (1998). The effect of pulp and paper mill effluent on an insectivorous bird, the tree swallow. Ecotoxicology, 7, 237-251.

Wiggins, G. B. (1996). Trichoptera families. In R. W. Merritt, \& K. W. Cummins (Eds.), An introduction to the aquatic insects of North America (3rd ed., pp. 309-349). Dubuque, Iowa: Kendall/Hunt. 